ARTUR MĘKARSKI

Łódź

\title{
MIĘDZY MITEM A POLITYCZNĄ RACJONALNOŚCIĄ. MYŚL HISTORYCZNA PAWŁA JASIENICY I JEJ RECEPCJA W DOBIE POLSKI LUDOWEJ
}

\begin{abstract}
Wstęp
„Po śmierci Stalina, około roku 1954 zorientowałem się, że już nie jestem skazany na współpracę z PAX-em. Ale już do Tygodnika nie mogłem wrócić. Wobec tego zacząłem pisywać w różnych pismach, jak Nowa Kultura czy Przegląd Kulturalny, a nawet w Życiu Warszawy o początkach historii Polski. Zresztą nie tylko, bo także o innych sprawach. Z tego powstała myśl napisania historii Polski takiej dla ludzi, bo obecne podręczniki... sama wiesz [podkr. A.M.]"1 - w taki oto sposób pod koniec 1960 r. w prywatnej rozmowie z Hanną Rudzińską wyjaśniać miał Paweł Jasienica pobudki i okoliczności, które sprawiły, iż postanowił po swojemu opowiedzieć dzieje Polski. W idei napisania dzieła „dla ludzi” nie kryła się wyłącznie troska o czytelnika z trudem tylko radzącego sobie z naukowym żargonem i oczekującego w związku z tym tekstu, którego warstwa formalna nie byłaby barierą w zrozumieniu treści. Choć retoryka miała duży udział w odebraniu podręcznikom z lat pięćdziesiątych XX w. ludzkiej twarzy, to przecież chodziło Jasienicy nie tylko o ich formę, ale również o treść, czyli o względy jak najbardziej merytoryczne. Mówiąc wprost: Jasienica zaczął pisać swoje książki w wyraźnej opozycji do stalinowskiej wizji dziejów Polski, w tym szczególnie w opozycji do jej metodologicznych fundamentów, które wiązały się z projektem wdrożenia w historiografii stalinowsko-marksistowskiego schematu formacji społeczno-ekonomicznych. Sprzeciw wobec założeń teoretyczno-metodologicznych, które
\end{abstract}

${ }^{1}$ H. Rudzińska, Rozmowy z Pawłem Jasienica, „Zeszyty Historyczne” (Paryż) 2000, 134, s. 182. 
zawładnęły historiografią Polski Ludowej w totalitarnym okresie jej dziejów, stanowił zrazu istotny wyróżnik jego książek i ważny kontekst ich powstania. Odrzucenie teorii, która nie tylko fundowała obraz przeszłości, ale również sankcjonowała budowę nowego ustroju i przejęcie władzy przez komunistów, sprawiało, że traktowano jego dzieła jako wyraz sprzeciwu (możliwego za sprawą historycznego kostiumu, w który był ubrany) wobec nowych porządków, niezależnie zresztą od tego, iż - zwłaszcza patrząc $\mathrm{z}$ dzisiejszej perspektywy - poglądy Jasienicy w wielu miejscach $\mathrm{w}$ istotnej mierze komponowały się z „polityką historyczną” komunistycznej władzy. Niewątpliwy talent literacki autora, służąc niezłomnie tradycyjnej historiografii, tylekroć strawniejszej dla szerszej publiczności aniżeli jej socjologizująco-ekonomizujące wersje, sprawiał, że autor Polski Jagiellonów zyskał dużą popularność, stając się wyjątkowym zjawiskiem na kulturalnej mapie Polski Ludowej. Z tego jednak względu warto przyjrzeć się jego twórczości w sposób bardziej kompleksowy, nie ograniczając się wyłącznie do wyszukiwania w jego dziełach politycznych komentarzy i odniesień do współczesności. Bywa to bowiem ryzykowne i może prowadzić na interpretacyjne manowce.

Poniższe rozważania składają się z dwóch części. Pierwsza poświęcona została analizie myśli historycznej Jasienicy, druga zaś recepcji jego dzieł w dobie Polski Ludowej. W części pierwszej, charakteryzując główne zręby myśli historycznej autora Słowiańskiego rodowodu, wyodrębniłem dwie fazy w jej rozwoju. Pierwsza z nich przypadła na koniec lat pięćdziesiątych. Powstały wówczas takie prace, jak Polska Piastów, Polska Jagiellonów czy Myśli o dawnej Polsce. W fazie tej apologii Polski piastowskiej towarzyszyła surowa krytyka Polski jagiellońskiej. Co zaś szczególnie istotne, $\mathrm{w}$ antytetyczne zestawienie dokonań obu dynastii wpisany był mit założycielski, stanowiący jądro zaproponowanej przez Jasienicę koncepcji dziejów Polski. Druga z wyróżnionych przeze mnie faz łączyła się z powstaniem trylogii relacjonującej dzieje Rzeczypospolitej Obojga Narodów, chronologicznie obejmując połowę lat sześćdziesiątych. Fazę tę wyróżniała retrospektywna rehabilitacja państwa Jagiellonów, a także pewne poszerzenie horyzontu metodologicznego historyka. Na obecnym etapie badań impuls, który zadecydował o istotnej rewizji poglądów „endeka z Wilna” na dzieje Polski, pozostaje tajemnicą. Z kolei część druga podejmuje wątki, które - w mojej opinii - zasługują na wyodrębnienie w kontekście recepcji prac Jasienicy w dobie Polski Ludowej. 
W kręgu myśli historycznej Pawła Jasienicy

\section{Elementy refleksji teoretyczno-metodologicznej}

Nierzadka wśród profesjonalnych historyków podejrzliwość wobec historiozoficznych spekulacji cechowała również Jasienicę. Przeświadczenie, iż dzieje stanowią realizację logicznego wzoru, nie tylko wypaczało obraz przeszłości - skomplikowana materia dziejów nie poddawała się bowiem dominacji zawsze za ciasnych i nieelastycznych schematów ale było również, paradoksalnie, świadectwem abdykacji rozumu z dążenia do racjonalnego kształtowania ludzkiego życia. Skoro społeczeństwo mocą wewnętrznego mechanizmu dziejów zmierzało do stanu idealnego bądź ideałowi bliskiego, wystarczyło uzbroić się w cierpliwość, dając się nieść nieuchronnej i rozumnej trajektorii dziejów. Tymczasem porządek natury z jednej i porządek kultury z drugiej strony funkcjonowały w obrębie zupełnie różnych reguł. Jasienica pisał:

zamiłowanie do uproszczeń skłania zazwyczaj do poszukiwania wszystko wyjaśniającej formuły. Nazywa się to niekiedy ustalaniem praw dziejowych czy też rozwoju społecznego [--] Zdaniem fachowców przyroda zachowuje się tak, jakby dbała tylko o zachowanie jak największej ilości gatunków, a cierpienia osobnicze były jej obojętne. Jeżeli to praw$\mathrm{da}$ - historia jest stokroć bardziej niemiłosierna od przyrody. Marnuje zdobycze całych społeczności zaprzepaszcza i je same. Kto upiera się patrzeć tylko od strony osiągnięć, które się jako tako utrwaliły, ten ma w oczach pozór logiki i sensu. Prawa historii zaczynają wyglądać podejrzanie, jeśli spojrzeć od strony ruin, czyli tego, co przepadło z niewątpliwą szkodą dla powszechności².

„W sporadycznych wypadkach - pisał na temat historiozoficznych formuł Jasienica - mamy do czynienia z czymś, co zdecydowanie przypomina magię"3. Filozoficzne teorie dziejów promowały historiografię, która sprawiała, że ludzie byli nieczuli na pojawiające się zagrożenia, nieskorzy do wysiłków reformatorskich, oddani na pastwę historiozoficzno-politycznych ideologii. To te ostatnie wspierały niegdyś wiarę szlacheckiej braci, iż ustrój Rzeczypospolitej Obojga Narodów odzwierciedlał porządek niebieski, gwarantując państwu bezpieczną egzystencję. To one doprowadziły romantyków do przekonania, iż Polska jest Mesjaszem narodów. Taka historiografia nie mogła być mistrzynią dobrej polityki. $Z$ metodologicznego

\footnotetext{
${ }^{2}$ P. Jasienica, Polska anarchia, Warszawa 1988, s. 47.

${ }^{3}$ Ibidem, s. 46.
} 
punktu widzenia powyższe poglądy prowadziły do rehabilitacji tradycyjnej historii politycznej. Jasienica pisał z nutą wyraźnej ironii:

Powiedzieć, że zgodna współpraca Jagiełły, Witolda i Skirgiełły doprowadziła do prawdziwego zjednoczenia Litwy - to haniebny personalizm. Przemilczeć świadomą celu pracę tych polityków, a powołać się na «tendencję» - oto właściwy sposób postępowania ${ }^{4}$.

Eksponując historyczne znaczenie ośrodków władzy - co czynił w opozycji do poglądów głoszących, iż punkt ciężkości badań historycznych powinien ulec przesunięciu z działań jednostek na procesy o charakterze masowym - często przytaczał swój ulubiony argument, związany z potencjalnymi skutkami zastosowania broni masowego rażenia. Podkreślał, iż decyzja nielicznej grupy przywódców politycznych, mających dostęp do pocisków uzbrojonych w głowice atomowe, może przyczynić się do bardzo radykalnego cięcia w dziejach całego świata. Można by tu sformułować zastrzeżenie, mówiąc, iż argument powyższy nie znajdował zastosowania do okresów, na których temat Jasienica pisał swoje książki. To dopiero bowiem postęp technologiczny XX stulecia dał politykom taką niezwykłą „cezurotwórczą” moc. Autor Polski Piastów zaznaczał, że to właśnie doświadczenia współczesnego świata przekonywały go o pierwszorzędnej roli, jaką odgrywały w dziejach sprawujące władzę jednostki względnie związane z nimi grupy władzy. W tym kontekście dość przewrotnie pisał:

Przygląadając się historii najnowszej całkiem łatwo zauważyć, iż komuniści są tymi, którzy szczególnie dbają o ośrodek myśli i władzy politycznej. Strzega jego jednolitości oraz zwartości, tak że dzieje powszechne znają tylko jedną analogię - kościół katolicki ${ }^{5}$.

Omówione powyżej stanowisko zawierało krytykę, której ostrze, trafiając bez wątpienia w stalinowską teorię historii, z natury rzeczy godziło we wszelkie filozofie dziejów. Niemniej poza refleksją o zasięgu uniwersalnym w teoretycznych rozważaniach Jasienicy znajdujemy także uwagi, które odnosiły się wyłącznie do teorii formacji społeczno-ekonomicznych.

Teoria ta stawiała w centrum konflikty klasowe, których doniosłości Jasienica nie negował. Akceptował myśl, iż stanowiły one wyraz autentycznego doświadczenia ludzkości - w tym przynajmniej sensie, w jakim za coś oczywistego uznać należy konflikty między biednymi a bogatymi przebiegające ponad granicami poszczególnych państw i mieszczące się

\footnotetext{
${ }^{4}$ Ibidem.

${ }^{5}$ P.Jasienica, rec.: M. Bloch, Pochwała historii, „Kultura i Społeczeństwo” 1961,1, s. 235.
} 
w odrębnym rytmie historii. W tej społeczno-kosmopolitycznej perspektywie teoria formacji mogła aspirować do miana głównego narzędzia periodyzacyjnego. „Miarę kapitalizmu i feudalizmu można sobie swobodnie przykładać do historii całej Eurazji i innych części świata. [- - ] Nie odmawiam nikomu - pisał - prawa do tworzenia wielkich syntez, ogarniających tysiąclecia i całe kontynenty"6. Niemniej przyjęcie tak szerokiej perspektywy nie pozwalało na uchwycenie kluczowych ogniw łańcucha tworzącego dzieje poszczególnych państw i narodów. „Ale jeśli z szerokiej rzeki historii powszechnej postanowił ktoś wyróżnić dzieje Polski i omówić je osobno, to niechże nie głuchnie na ich jedyny w swoim rodzaju rytm"7. Centralne obiekty dziejopisarskich relacji, takie jak naród czy państwo, zyskiwały w ramach rozwoju historycznego swoją autonomię, a konflikty, na które były narażone, krzyżowały się z kosmopolitycznie rozumianymi konfliktami klasowymi. Polityką państw rządziły na przykład interesy dynastyczne, które biegły niejako w poprzek interesów klasowych.

Koronny argument, wyrażający sprzeciw Jasienicy wobec interpretacji sprowadzającej dzieje Polski do roli lokalnej ilustracji historiozoficznego schematu teorii formacji, wiązał się zatem z dążeniem do ocalenia specyfiki dziejów założonego przez Mieszka I państwa. Procedura periodyzacyjna, odwołująca się do chronologicznie rozległych formacji społeczno-gospodarczych, gubiła przeobrażenia nadające polskiej przeszłości odrębność i swoistość. „Krótko mówiąc, to żaden podział dziejów pisał - umieszczać w tym samym okresie Piasta, Rzepichę i Augusta Mocnego razem $z$ jego połamanymi podkowami oraz mnóstwem nieprawych dzieci. Jeśli unii z Litwą i rozbiorów nie uzna się za wyraźne granice epok, to cała przeszłość Polski utraci jej tylko właściwy charakter"8. Jasienica podkreślał zarazem, że konsekwentne stosowanie kryterium społeczno-gospodarczego przy wyodrębnianiu punktów zwrotnych w historii Polski kłóciło się z decyzją o poświęceniu osobnego tomu okresowi 19181939. Jego skrajne daty bowiem wyraźnie odwoływały się do kryteriów politycznych. „W chwili przewrotu majowego kapitalizm panował u nas akurat tak samo, jak dziesięć lat wcześniej, fabryki domy i grunty nie zmieniły właścicieli" 9 .

Sformułowana przez Jasienicę krytyka nie tylko zmierzała do ochrony autonomii sfery politycznej, której dynamika różniła się zasadniczo

\footnotetext{
${ }^{6}$ Idem, Tylko o historii, Warszawa 1962, s. 90-91.

${ }^{7}$ Ibidem, s. 91.

${ }^{8}$ Ibidem, s. 90.

${ }^{9}$ Ibidem, s. 91.
} 
od rytmu kształtującego relacje między klasami ekonomicznie uprzywilejowanymi z jednej i materialnie upośledzonymi z drugiej strony. Przytoczone wyżej komentarze wskazywały również na nieuchronną kolizję między podrzędnym statusem przysługującym państwu w obrębie teorii materializmu historycznego a pierwszorzędną rangą, którą zapewniała mu tradycja historiograficzna. Na gruncie teorii formacji w państwie widziano element nadbudowy służący konserwacji klasowych przywilejów, skazany na obumieranie wraz z przybliżaniem się do epoki społeczeństwa bezklasowego. Tradycja historiograficzna natomiast sankcjonowała pozycję państwa jako niekwestionowanego podmiotu dziejów. W obrębie wspomnianej tradycji zarówno z aksjologicznego, jak i ontycznego punktu widzenia państwo zachowywało absolutny prymat. Z aksjologicznego, gdyż urzeczywistnianie wszelkich wartości było tu raczej nie do pomyślenia poza jego obrębem; z ontycznego, gdyż jako optymalny sposób organizacji życia zbiorowego było bytem w zanik którego, czyli eliminację z inwentarza rzeczywistości, raczej wewnątrz tej tradycji nie wierzono. W ramach zaś historiozoficznego schematu teorii formacji jego status był zdecydowanie drugorzędny. W pierwszym przypadku budowa silnego państwa była wartością niekwestionowaną. W drugim $\mathrm{w}$ istocie blokowała przekroczenie progu, za którym dopiero możliwa staje się realizacja głęboko humanistycznych wartości. Trudno było wskazać na wszelkie węzłowe momenty w dziejach państwa, odwołując się do teorii widzącej w nim byt przygodny, który w tej samej mierze, w jakiej służył pomnażaniu wartości, służył jednocześnie - i to znacznie częściej - ich destrukcji. Przyłożona do dziejów państw, skutkowała wyodrębnieniem tylko tych zjawisk i wydarzeń z historii owych państw, które rozgrywały się w płaszczyźnie walki społecznej o wyzwolenie z klasowego ucisku. Dzieje państwa stawały się tu przedmiotem zabiegów periodyzacyjnych, ale niejako tylko „przy okazji”. Można sobie wyobrazić całą gamę fundamentalnych z punktu widzenia organizmu państwowego przekształceń, które były obojętne w odniesieniu do panujących w nim stosunków społecznych (np. reformy armii, zmiany ustroju politycznego). Doszukiwanie się w niemal każdym poruszeniu życia politycznego „treści klasowej” nie rozwiązywało, jak się zdaje, tego problemu. W okresie stalinowskim, czyli w okresie, w którym historiografia musiała się „zmagać” ze szczególnie wzmożoną ekspansją teorii formacji, problem ten zaznaczył się wyraźnie w decyzji, by rok 1795 usunąć z rzędu przełomowych momentów w dziejach Polski. We wstępie do stalinowskiej Makiety dziejów Polski redaktorzy tego zbiorowego dzieła stwierdzali, iż upadek państwa nie zasługiwał na rangę cezury, gdyż zarówno przed tą datą, jak i po niej utrzymywały się na ziemiach polskich te same formy 
feudalnego ucisku ${ }^{10}$. $\mathrm{z}$ tego względu sama inicjatywa, by przedstawić dzieje Polski (czyli dzieje państwa), posługując się narzędziami konceptualnymi wypracowanymi w łonie materializmu historycznego (czyli teorii, dla której państwo nie jest fundamentalnym bytem historycznym i periodyzacyjnym punktem odniesienia), zdawała się zadaniem poniekąd karkołomnym.

Jasienica nie przeczył, iż zakres ludzkich możliwości wyznaczały obiektywne procesy społeczne charakteryzujące się niezwykłą inercją. „Główny nurt historii - przyznawał - kształtują zjawiska niezależne od woli działających osób, a nawet pokoleń” ${ }^{11}$. Jednak stwierdzał: „w szerokich ramach, stworzonych przez konieczności wynikłe z ogólnego rozwoju warunków ludzkiego bytowania, jest dość miejsca na postanowienia i czyny rozstrzygające o szczęściu i nędzy, nawet o życiu i śmierci całych narodów"12. W ocenie Jasienicy uznanie obiektywnego charakteru zjawisk społecznych (obiektywnego, tj. dotyczącego zwykle długo się utrzymujących społecznych stanów rzeczy ograniczających subiektywną wolę indywidualnych aktorów dziejów i zbiorowe, nieprzewidziane rezultaty ludzkich działań) w żadnej mierze nie uszczuplało dziejowego znaczenia sfery politycznej. Uważał bowiem, że „konieczność historyczna - to po prostu główny problem do rozwiązania w danej epoce. Ale samo rozwiązanie może wypaść dobrze albo źle" ${ }^{13}$. Wskazując, iż obiektywna strona procesu historycznego nie umniejsza wyjątkowego znaczenia polityki, gdyż to zawsze w rękach władzy spoczywają decyzje stanowiące odpowiedź na te niedające się przewidzieć okoliczności ludzkiego istnienia,Jasienica nie dostrzegał, iż przynajmniej część z tych procesów przebiegała nie tylko niezależnie od woli danych jednostek, ale również poza ich świadomością i nie mogła w związku z tym być kwestią „do rozwiązania”. Zarówno problemy ekonomiczne, jak i zawirowania polityczne wywoływane były zjawiskami, z których sobie nie zdawano sprawy i których natury nie rozumiano (inflacja, ruchy demograficzne).

Warto dodać, iż od uznania, że obok świadomych ludzkich działań dzieje wypełniają procesy niezależne od woli najlepszych nawet władców, był tylko krok do wysunięcia postulatu nakazującego wiązanie obiektywnej i subiektywnej strony procesu dziejowego. Tę dyrektywę zaś nieustannie lansował w inspirowanych marksizmem pracach metodologicznych Jerzy

${ }^{10}$ Historia Polski. Makieta, t. 2, cz. 1: 1764-1814, red. S. Kieniewicz, W. Kula, Warszawa 1956, s. 5-6.

${ }^{11}$ P. Jasienica, Tylko o historii, s. 92.

${ }^{12}$ Ibidem.

13 O historii po heretycku. Z Pawłem Jasienica w imieniu Polityki rozmawia Krystyna Nastulanka, „Polityka” 1960, 48. 
Topolski ${ }^{14}$. W poglądach Jasienicy (choć głównie na poziomie refleksji teoretycznej) widać zatem również wpływ modernizujących tendencji dokonujących się w łonie historiografii także za sprawą elastycznie interpretowanego marksizmu. Fakt, iż w swoich pracach zajmował się głównie subiektywną stroną procesu historycznego, tłumaczył tym, że - inaczej niż uniwersyteccy historycy - jest on tylko publicystą pisującym historyczne eseje.

W niektórych wypowiedziach o tematyce teoretyczno-metodologicznej Jasienica nawiązywał do mającego długą tradycję sporu między optymizmem a pesymizmem dziejów Polski. Zabiegał tu o swoistą równowagę między optymistyczną a pesymistyczną prezentacją polskiej przeszłości. Nie uważał, aby jego twórczość należało wiązać z nurtem optymistycznym, gdyż nawet dynastia Piastów - którym jego zdaniem zawdzięczała Polska najlepszy okres swoich dziejów - przedstawiona została w jego pracach jak „czereda diabłów”"15. Sprzeciw jego budziły też skrajnie pesymistyczne ujęcia narodowej przeszłości. Taka pesymistyczna historiografia z kolei nie mogła liczyć na znaczący rezonans społeczny, na którym wszak powinno zależeć nawet najbardziej naukowo nastawionym historykom. Krytykując pesymistyczne ujęcia dziejów Polski, atakował zarazem - przynajmniej pośrednio - teorię formacji. Pesymizm był bowiem niejako strukturalnie w tę teorię wpisany. Rozłupanie dziejów na dwie części, tj. na okres przed rewolucją proletariacką i ten następujący po niej, stanowiło kluczową cezurę w obrębie historiozoficznego schematu teorii formacji społeczno-ekonomicznych. Świat w erze przedsocjalistycznej to świat wartości pozornych, to rzeczywistość wypełniona konfliktami klasowymi, a budowa socjalizmu miała oznaczać przekroczenie tych konfliktów i autentyczną realizację wartości fundamentalnych. Ponieważ zaś rewolucja proletariacka dokonała się zasadniczo w teraźniejszości, a ujęcia przeszłości, jakie skłonni byli zaakceptować przywódcy rewolucji, miały eksponować przełomowy w porównaniu z poprzednimi charakter nowej epoki, cała przeszłość malowana była w barwach niezwykle ciemnych ${ }^{16}$. Odpowiadając na krytyczne recenzje wydawnicze z Polski Jagiellonów, napisane, jak wspominał Jasienica, ,z marksistowskiego punktu widzenia” przez Henryka Łowmiańskiego i Romana Hecka, autor recenzowanej pracy, odrzuciwszy postulat przyjęcia „słusznej” perspektywy metodologicz-

${ }^{14}$ R. Stobiecki, Między dogmatem ideologicznym a modernizacja. Marksizm a historiografia w Polsce po drugiej wojnie światowej, w: idem, Historiografia PRL. Ani dobra, ani madra, ani piękna..., ale skomplikowana. Studia i szkice, Warszawa 2007, s. 179.

${ }^{15}$ Dyskusja nad społeczna funkcją historii. Głos Pawła Jasienicy, „Więź” 1961, 7/8, s. 34.

${ }^{16}$ Patrz: R. Stobiecki, Stalinowska mitologizacja idei postępu, w: Historia - mity - interpretacje, red. A. Barszczewska-Krupa, Łódź 1996, s. 139-147. 
nej, odpowiadał, iż „nie zamierza się przyczyniać do smarowania dziegciem historii własnego kraju"17.

\section{Między apologią Polski piastowskiej a krytyką Polski jagiellońskiej}

Czerpiąc pełnymi garściami z dorobku polskiej historiografii, również, i to w niemałym stopniu, tej dziewiętnastowiecznej,Jasienica przejmował charakterystyczne dlań sposoby konceptualizowania przeszłości. $Z$ pewnością zaliczał się do nich zwyczaj umieszczania dziejów Polski w obrębie dziejów Zachodu jako pewnej szerszej całości, którą wyodrębniano rzecz jasna nie ze względów czysto geograficznych, lecz kulturowych i cywilizacyjnych, widząc w niej normatywny wzorzec i oparcie dla sądów formułowanych w odniesieniu do narodowej przeszłości. Europejski kontekst wykorzystywano zazwyczaj w diagnozie stanu rozwoju dziejowego Polski, stwierdzając już to jego prawidłowość, już to jego liczne patologie i anomalie, które często obciążano odpowiedzialnością za upadek państwa w drugiej połowie XVIII w. Do tych kanonów nawiązywała myśl historyczna Jasienicy, który również starał się mierzyć dzieje Polski zachodnią miarą, tworząc z niej podobnie jak jego słynni poprzednicy - podstawowe narzędzie periodyzacyjne. Zwłaszcza w pierwszej fazie swojej twórczości historycznej dał wyraz poglądom, w których centralne miejsce zajmowała teza o anomalii rozwoju dziejowego Polski, do której doszło w wyniku przejęcia władzy przez obcą polskiej tradycji dynastię Jagiellonów.

Antytetyczne zestawienie Polski Piastów z Polską Jagiellonów związane $\mathrm{z}$ apologią tych pierwszych i krytyką drugich jest najbardziej rzucającą się w oczy cechą pisarstwa Jasienicy z okresu, w którym powstały Polska Piastów, Polska Jagiellonów oraz Myśli o dawnej Polsce. Do porównań między Piastami i Jagiellonami odwoływał się autor wielokrotnie, eksponując zazwyczaj rozmiary niekorzystnych zmian, do których doszło w wyniku unii Polski z Litwą. Taka diachroniczna komparatystyka kryła w sobie tendencję do homogenicznego traktowania obu dynastii (zwłaszcza piastowskiej) jako osobnej całości zasługującej na jednorodną, zbiorową ocenę. $Z$ tego względu podążenie tropem tego piastowsko-jagiellońskiego zestawienia nie tylko nie wypacza myśli Jasienicy, lecz, jak sądzę, oddaje jej w pełni sprawiedliwość, stanowiąc zarazem uzasadnioną strategię prezentacji jego dorobku.

Zdaniem Jasienicy władcy z rodu Piastów stosowali się do najlepszych europejskich norm kultury i praktyki politycznej. Mieszka I i jego następców wyróżniał umiar, niechęć do angażowania się we wszelkie przedsięwzięcia daleko poza granicami kraju oraz „obracanie sił przede

${ }^{17}$ P. Jasienica, Pamiętnik, Kraków 1989, s. 96. 
wszystkim na scalanie polskich ziem gniazdowych" ${ }^{18}$. Jagiellonowie natomiast sprowadzili do Polski tradycję nieporównanie niższej kultury politycznej. „Zamiast gruntowności - klajstrowanie” idące w parze ze skłonnością do niepotrzebnego rozmachu, ,efektownych zdobyczy i pozostawiania mnóstwa spraw w zawieszeniu”. Zgoła „niepolitycznym” zwyczajem było jakże charakterystyczne dla przedstawicieli litewskiej dynastii „beztroskie podejmowanie działań na wielu frontach" ${ }^{\text {. }}$. Na postępowaniu Jagiełły i jego następców silnie ciążyła tradycja wypraw łupieskich ,prowadzonych na wszystkie strony, bez żadnej myśli przewodniej”20. „Może się mylę - pisał - ale dynastyczna polityka jagiellońska wygląda moim zdaniem na spadek po najpierwotniejszym okresie dziejów Litwy". Czynami Piastów rządził pragmatyzm. Bez oporów zawierali sojusze z poganami. Nie traktowali różnic religijnych jako okazji do eskalowania konfliktów. „Aż do Kazimierza Wielkiego włącznie brak w świeckiej historii kraju dowodów wrogości wobec prawosławia i prawosławnych. Zmienić się to poniekąd miało dopiero za nowej dynastii, za króla neofity, który musiał podkreślać swą katolicką prawowierność” ${ }^{21}$. Właśnie w czasach jagiellońskich „polityka polska bez zastrzeżeń poszła w służbę ideologii”. „Pomału zaczynała się Polska uznawać za obarczoną polityczną misją obrony katolicyzmu"22. Jak podkreślał Jasienica, gotowość do organizowania akcji antytureckich podyktowana właśnie względami ideologicznymi przyszła w czasie, gdy już „nikt w Europie o żadnym zbiorowym wystąpieniu przeciwko Turkom nie myślał, każdy pilnował własnego dobra i już bez ceremonii odrzucał resztki uroszczeń papiestwa oraz cesarstwa" ${ }^{23}$. Wówczas właśnie, tj.już w XV w. „ścieżka naszej historii zaczynała odbiegać od zwykłych europejskich dróg" ${ }^{24}$.Śmierć Władysława Warneńczyka w 1444 r. była jakby zapowiedzią „nieszczęść czekających Polskę na szlakach, które nie były jej własnymi drogami”"25. Ryzyko, jakie podjął wówczas młody władca, nie miało żadnego poza ideologicznym uzasadnienia. Zupełnie inaczej postępowali władcy $z$ rodu Piastów. Łokietek, rozumiejąc, że Polska nie może stracić następcy tronu, zwyczajnie kazał wycofać się z pola walki Kazimierzowi, kiedy jego życie znalazło się w niebezpieczeństwie. „Postępek - podsumowywał Jasienica - wcale przezorny. Na zimno widać wyrachowany. Po gospodarsku

\footnotetext{
${ }^{18}$ Idem, Polska Jagiellonów, Warszawa 1963, s. 207.

${ }^{19}$ Ibidem.

${ }^{20}$ Idem, Myśli o dawnej Polsce, Warszawa 1960, s. 215.

${ }^{21}$ Idem, Trzej Kronikarze, Warszawa 1964, s. 206.

${ }^{22}$ Idem, Polska Jagiellonów, s. 164.

${ }^{23}$ Ibidem, s. 163.

${ }^{24}$ Ibidem, s. 165.

${ }^{25}$ Ibidem, s. 171.
} 
trzeźwy" ${ }^{26}$. Oceniając wplątanie się Polski w konflikt ze Szwecją o Inflanty w czasach Zygmunta Augusta pisał:

Jeśli się konsekwentnie chciało przymierza ze Szwecją przeciwko Moskwie, to należało raczej zabiegać, aby kandydat na sojusznika usadowił się w części Inflant, sam osobiście stanął carowi na drodze. To by dopiero uczyniło zeń rzeczywistego wspólnika. W ówczesnym postępowaniu Rzeczypospolitej wprost widać skutki niedobrej szkoły politycznej, która wraz z Jagiellonami przyszła na Wawel ${ }^{27}$.

Polityka prowadzona przez Jagiellonów miała na celu realizację interesów dynastycznych, które nie pokrywały się z interesem państwa. Natomiast monarchia ostatnich Piastów stanowiła „najbardziej postępowy na owe czasy typ ustroju politycznego”. Była bowiem monarchią narodową „zmierzającą do skupienia w jedną całość ziem zamieszkanych przez Polaków”. W monarchii tej „interes panującego i kraju - to jedno" 28 . Autor Polski Jagiellonów podkreślał, że władcy piastowscy bardzo dbali o zapewnienie sobie stałej przewagi majątkowej nad rzeszą możnych posiadających znaczenie polityczne. Jednak już w stosunku do Jagiellonów podobnego wniosku nie można było sformułować. Również proces systematycznie pogarszającego się położenia mieszczan i towarzysząca mu zgubna dominacja stanu szlacheckiego w Rzeczypospolitej Obojga Narodów wynikał z błędów popełnionych przez przedstawicieli nowej dynastii. Porównując politykę, jaką wobec słabnącego od XV w. mieszczaństwa prowadził Kazimierz Wielki, z postępowaniem Kazimierza Jagiellończyka, Jasienica wskazywał, iż ten pierwszy „wciągał mieszczan do akcji politycznych. Wiązał ich w całość, dbał o nich jako stan". Takiej troski nie przejawiał drugi z wymienionych właśnie władców. „Przy całym - pisał Jasienica - szacunku dla charakteru i umysłu Kazimierza Jagiellończyka trzeba stwierdzić, że w tej sprawie zawiódl"29.

O tym, że po unii Polska zaczynała „wypadać z europejskiego rytmu, opóźniać krok", świadczyły zmiany, które dotknęły Akademię Krakowską. W czasach Jagiełły, argumentował Jasienica, położono tam szczególny nacisk na studia teologiczne. Świeżo nawrócona Litwa potrzebowała księży, podobnie jak kilkaset lat wcześniej Polska. Stąd zrozumiały zwrot w kierunku teologii. Tyle tylko, że tym razem oznaczał on dostrajanie uniwersytetu do „wymagań ogromnie zapóźnionych”. Reforma uniwersyteckiego sylabusa przeprowadzona została w dobie, kiedy „dawny średniowieczny

\footnotetext{
${ }^{26}$ Idem, Polska Piastów, Warszawa 1983, s. 295.

${ }^{27}$ Idem, Ostatnia z rodu, Warszawa 1965, s. 128.

${ }^{28}$ Idem, Polska Piastów, s. 310.

${ }^{29}$ Idem, Polska Jagiellonów, s. 201.
} 
teocentryzm trzymał się już tylko siłą bezwładu, kiełkowały zapowiedzi Renesansu”, a „Europa obracała się w stronę świecką"30.

W krytyce unii z Litwą Jasienica nawiązywał niewątpliwie do tzw. teorii przestrzeni, która swój najdobitniejszy wyraz znalazła w twórczości Michała Bobrzyńskiego ${ }^{31}$, choć odnaleźć ją można również w twórczości innych historyków (np. Wacław Sobieski). Głosiła ona, iż idący w ślad za unią terytorialny rozrost państwa skutkował roztrwonieniem swoistej zbiorowej energii na jego nowym i nienaturalnie powiększonym obszarze. Skumulowana wewnątrz kraju o mniejszych, gniazdowych gabarytach energia ta stałaby się zarzewiem zbawiennych konfliktów społecznych. Zmagające się ze sobą stany zabiegałyby bowiem o poparcie korony, co wzmacniałoby ją w stopniu gwarantującym możliwość przeprowadzania w przyszłości niezbędnych reform, które właśnie z uwagi na siłę magnaterii z jednej i słabość władzy królewskiej z drugiej strony przeprowadzone być nie mogły. Do tego rodzaju argumentacji odwoływał się Jasienica, pisząc: „Obszar państwa! - czynnik o znaczeniu pierwszorzędnym. To on wpłynął na stopniowe słabnięcie napięć socjalnych w królestwie polsko-litewskim, wytworzył pozory wrodzonego niedołęstwa mieszkańców”32. „Niezadowoleni - pisał w innym miejscu $-\mathrm{z}$ istniejących porządków, zamiast walczyć o ich odmianę, mogli zmienić miejsce pobytu. W tych okolicznościach wszelkie zapały reformatorskie bladły, traciły wigor"33.

Jasienica podkreślał, że zawierając unię, została Polska wciągnięta w niepotrzebne konflikty z Rosją. Włączając się do walki między Moskwą a Litwą o panowanie nad ziemiami ruskimi, przystępowała do rozgrywki dotychczas całkowicie sobie obcej, a noszącej „,charakter zapasów śmiertelnych" ${ }^{34}$. Zasadą polityki piastowskiej była pokojowa polityka wobec państwa moskiewskiego. Spory, do których czasami dochodziło, miały charakter drobnych, granicznych zatargów.

Rozszerzenie skierowanego przeciwko unii aktu oskarżenia o zarzut rujnujących kraj konfliktów z Rosją przypominało krytykę formułowaną najostrzej w okresie stalinowskim. Stanowisko Jasienicy jednak w istotny sposób różniło się od interpretacji wyłożonych w stalinowskich podręcznikach, które miały być precyzyjną artykulacją historiozoficznego modelu teorii formacji. Jej koronna teza głosiła, iż rdzeń dziejów

${ }^{30}$ Ibidem, s. 96.

${ }^{31}$ J. Maternicki, Michał Bobrzyński wobec tzw. idei jagiellońskiej. Ewolucja poglądów i jej uwarunkowania, w: idem, Kultura historyczna dawna i współczesna. Studia i szkice, Warszawa 1979 , s. $144-161$.

32 P. Jasienica, Polska Jagiellonów, s. 355.

${ }^{33}$ Ibidem, s. 418.

${ }^{34}$ Idem, Myśli o dawnej, s. 251. 
stanowi walka klas prowadzona w imię zaspokojenia interesów materialnych warstw uprzywilejowanych, których naturalnym dążeniem było konserwowanie dominującej pozycji. Unia z Litwą stanowiła właśnie doskonały wyraz takiej klasowej, ekspansywnej polityki. Wskutek agresywnej postawy polskiej magnaterii zmierzającej do podporządkowania sobie coraz większych terytoriów w celu ich bezwzględnej eksploatacji, kraj został narażony na zgubne w swoich konsekwencjach zderzenie z Rosją. Jasienica natomiast podkreślał, iż błędne jest utożsamianie zadzierzgniętego związku z Litwą z ideą ekspansji wschodniej, gdyż ta „już przed unią była faktem zupełnie dokonanym przez Litwinów"35. Odpowiedzialność za kłopoty, z którymi musiało się zmagać państwo polsko-litewskie, ponosili nie Polacy i ich zaborcze dążenia, lecz Litwini. W ramach sojuszu dwóch narodów nie tylko „Polska bez porównania więcej dała niż wzięła" ${ }^{36}$, ale to ona właśnie cierpiała na skutek jawnie ekspansywnego zachowania magnaterii litewskiej, skorej ponadto do zawłaszczania kluczowych stanowisk w państwie. To przedstawiciele litewskich rodów wnosili w poczynania zunifikowanego państwa polityczny prymitywizm. To oni torpedowali próby reform. Ich postawę charakteryzował Jasienica hasłem: „Litwa dla Litwinów. Polska dla Litwinów również"37.

Zarówno kłopoty w polityce zagranicznej, jak również degeneracja urządzeń ustrojowych nie były konsekwencją klasowej polityki polskiej magnaterii, ale skutkiem importu wyrastającej z obcej tradycji praktyki politycznej. Autor Polski Jagiellonów widział w unii swego rodzaju przeszczep - jeśli nie obcej cywilizacji, to z pewnością obcej kultury. Przeszczep nie tylko się nie przyjął, ale zatruł dotychczas zdrowy piastowsko-europejski organizm. Wraz z unią zaprzepaszczone zostały także wszelkie walory państwa narodowego. W sąsiadujących z Polską krajach istniała wyraźna tendencja do powoływania na tron „swoich”. W Rzeczypospolitej natomiast obawa, aby żaden ze współtworzących ją narodów nie zyskał zbyt dużej przewagi, doprowadziła do obioru władców obcych. Jasienica podkreślał, że szlachecka dominacja wewnątrz Rzeczypospolitej nie pokrywała się z dominacją żywiołu polskiego. „Polskie panowanie - pisał nie stanowiło treści dziejów tego państwa. Jego szlachta do jednolitości narodowej wcale się nie poczuwała. Tym mniej lud"38. Co więcej, szlachta wielkopolska i małopolska wychowana w szkole Piastów była wcale nieskora do prowadzenia zakrojonej na szeroką skalę ekspansji. „Zaczyna

\footnotetext{
${ }^{35}$ Ibidem, s. 266.

${ }^{36}$ Ibidem, s. 288.

${ }^{37}$ Idem, Ostatnia z rodu, s. 81-82.

${ }^{38}$ Ibidem, s. 211.
} 
nam - pisał Jasienica - zagrażać mit dość fantastycznie pojmowanego interesu klasowego oraz wynikających zeń rzekomo pragnień olbrzymiej ekspansji. W rzeczywistości pożądania panów małopolskich poza Podlasie, Wołyń i Podole nie sięgały" ${ }^{39}$. Polskopiastowski system immunologiczny okazał się za słaby, by uchronić zdrowy organizm przed rujnującym wpływem wspomnianego przed chwilą litewskiego prymitywizmu.

Gloryfikacja epoki Piastów posiadała silną podbudowę w postaci mitu założycielskiego. Wszystkie kluczowe wartości polityczne i wzory postępowania wyrażały mądrość poprzedników Mieszka I i Bolesława Chrobrego. Już wówczas, w czasach, na temat których wszelką wiedzę można było czerpać co najwyżej ze znalezisk archeologicznych, rozkwitł w całej pełni piastowski geniusz. Umiar i pragmatyzm w polityce zagranicznej, brak imperialnych ciągot, skłonność do kompromisów, szacunek dla regionalnych odrębności i tolerancja religijna wyróżniały już tę „prenatalną” fazę dziejów Polski. Jasienica podkreślał, że w okresie 963-1370 „zdarzył się tylko jeden wypadek przesadnego rozmachu" ${ }^{40}$. Poza rozumne zasady praktyki politycznej wykroczył Chrobry, próbując przyłączyć do Polski w latach 1003-1004 Czechy. Wybitny władca szybko jednak potrafił wrócić na właściwe tory. „Nauka nie poszła w las - pisał o Chrobrym Jasieni$\mathrm{ca}$ - nawet w tym człowieku, stanowczo przerastającym miarę swoich czasów, hamulce znowu zaczęły działać. Chrobry powrócił do szkoły przezorności, stworzonej przez ojca i d ziadów [podkr.A.M.]"41. Przekonany o niezwykłych zdolnościach założycieli kraju nad Wisłą, przychylał się Jasienica do interpretacji przedstawiającej Chrobrego jako „prawowitego, na zjeździe gnieźnieńskim wyznaczonego następcę Ottona i Ekkeharda"42. Podkreślając te niezwykłe osiągnięcia pierwotnego okresu w dziejach Polski, minimalizował rolę chrztu jako wydarzenia stanowiącego cywilizacyjny przełom. Chrzest nie stanowił przepustki do świata wyższej kultury politycznej, będąc raczej jedynie potwierdzeniem długiej już partycypacji w jej wartościach; „w dziedzinie kultury, nawet duchowej, żadnej astronomicznej odległości między Polską a Zachodem wtedy nie było"43. Władcy krajów zacofanych w zetknięciu z władcami państw reprezentujących wyższą kulturę „popadają w sybarytyzm. Starają się o taniutki zresztą luksus zagranicznego pochodzenia. Nie ma mowy o ich politycznym znaczeniu w świecie”44. Tymczasem, wskazywał, „gnieźnieńscy książęta we-

\footnotetext{
${ }^{39}$ Idem, Tylko o historii, s. 106.

${ }^{40}$ Idem, Myśli o dawnej, s. 79.

${ }^{41}$ Ibidem, s. 88.

${ }^{42}$ Idem, Podglebie, „Twórczość” 1960,2, s. 31.

${ }^{43}$ Ibidem, s. 34.

${ }^{44}$ Ibidem, s. 32.
} 
szli na wielką scenę krokiem pewnym, zachowywali się swobodnie, bez tremy. Skądże takie dyspozycje?" - pytał. Podkreślając emocjonalną gotowość do roli, jaką pierwszym polskim władcom wyznaczyła historia, Jasienica konstatował:

Pewność siebie umieją zachować ludzie doskonale zrośnięci ze swoim rodzimym środowiskiem i głęboko przekonani o jego wielkiej wartości. Tylko tacy bez wysiłku narzucają innym szacunek dla siebie, nie wywierają wrażenia podskakiewiczów. [--] Pozostają sobą ${ }^{45}$.

Rozum polityczny cechujący przedstawicieli dynastii piastowskiej był wyrazem kontynuacji wzorów skrystalizowanych w pierwotnym, formatywnym okresie dziejów Polski ${ }^{46}$. Ta właściwa linia postępowania urwała się wraz z przejęciem władzy przez dynastię, której obce były te pierwiastkowe zasady wyznaczające najgłębsze składniki politycznej tożsamości Polaków. Sprzeciw Jasienicy wobec interpretacji, która w unii z Litwą widziała klasowe, ekspansywne dążenia polskiej szlachty, wpisywał się wyraźnie w logikę mitu założycielskiego. W społeczeństwie uformowanym przez system, którego centrum polityczne konsekwentnie od Mieszka I do Kazimierza Wielkiego pozostawało wierne kanonowi postępowania, jaki ustanowili legendarni założyciele dynastii, zwyczajnie brakowało imperialnych, czyli sprzecznych z tym kanonem dążeń. Impulsem do zawarcia unii była gospodarska troska o rozwój wschodniej części Polski, który $\mathrm{z}$ uwagi na łupieskie wyprawy Litwinów był mocno ograniczony. W wywodach Jasienicy zabezpieczenie możliwości harmonijnego rozwoju wewnątrz gniazdowych ziem polskich poprzez alians z Litwą kładący kres ich najazdom miało - jeśli idzie o genezę unii - nawet większe znaczenie niż niebezpieczeństwo krzyżackie ${ }^{47}$.

Interpretacja eksponująca katastrofalne konsekwencje, jakie wynikały z łamania pierwiastkowych zasad polskiej polityki, odwoływała się do schematu posiadającego niezwykle odległą tradycję. Już w sarmatyzmie

${ }^{45}$ Ibidem, s. 33.

${ }^{46}$ W Polsce Jagiellonów czytamy takie oto uwagi: „Nawyki podyktowane przez setki lat historii to straszna potęga. One podlegają prawu dziedziczenia i kształtują oblicza środowisk ludzkich. Dynastia piastowska wyrosła z tych plemion, które - jedne jedyne z całej rzeszy słowiańskiej! - nigdy i nigdzie się nie ruszyły ze swych ziem ojczystych. Jakże nie dostrzegać związku pomiędzy tym faktem o podstawowym znaczeniu a dziedzicznymi skłonnościami Piastów, którzy byli bardzo nieustępliwi w sprawach autochtonicznych, polskich, na zewnątrz zaś chadzali niechętnie?” (P. Jasienica, Polska Jagiellonów, s. 207).

${ }^{47} \mathrm{Na}$ przykład w Słowiańskim rodowodzie Jasienica pisał: „Naczelnym jej [tj. unii A. M.] motywem była bowiem wcale nie żadna żądza zaborów na wschodzie, lecz odwrotnie - chęć zabezpieczenia wschodniej połaci państwa przed niszczącymi napadami" (idem, Słowiański rodowód, Warszawa 1978, s. 51). 
obowiązywał pogląd, że ustrój złotej wolności istniał w Polsce od zarania jej dziejów, a wszelkie kłopoty, z jakimi musiała zmagać się Rzeczpospolita, wynikały z degeneracji pierwiastkowych urządzeń ustrojowych ${ }^{48}$. Najsłynniejszym propagatorem tego sposobu mityzacji przeszłości był Joachim Lelewel ze swoją teorią pierwotnego gminowładztwa. Zdaniem Lelewela gminowładztwo, istniejące jeszcze w czasach przed Mieszkiem I, mieściło w sobie wszystkie fundamentalne wartości określające najgłębsze składniki polskości. Był to wzorcowy okres kryjący w sobie normy współżycia społecznego i politycznego, których podtrzymywanie było warunkiem pomyślności Polaków i podstawą właściwego funkcjonowania stworzonego przez nich państwa. Aktualna kondycja potomków Lecha oraz siła ich państwa zależała od zdolności do odtwarzania ustanowionego u zarania dziejów idealnego ładu ${ }^{49}$.

Jasienica występował przeciwko metafizycznym koncepcjom charakteru narodowego. Dający się wyśledzić w jego twórczości mit początku dotyczył raczej ufundowania wysokich standardów politycznego działania wiążących się z rozumem politycznym naprawdę szlachetnej, wysokiej próby. Rozum ten nie był jednak produktem historii. Jego działanie oznaczało odtwarzanie ustanowionego illo tempore transhistorycznego wzorca, wkraczając w obszar mitycznego wiecznego czasu teraźniejszego. Wysokie wskaźniki politycznego racjonalizmu uzyskane zostały w mocno zsakralizowanym otoczeniu. Co więcej, blask zasad wyznaczonych przez mitycznych fundatorów gnieźnieńskiego państwa ogarnął cały naród, wiążąc go w ten sposób ze świętą siłą pierwotnego ładu. Trudno się dziwić, iż sakralizując naród polski, umieszczał Jasienica poza nim źródła słabości państwa, odnajdując je w szkodliwym oddziaływaniu pierwiastka litewskiego degenerującego aksjologiczną tkankę zbudowaną z polskiej wyjątkowości, która jednak - należy dodać - wyrosła ze wspólnego ogólnoeuropejskiego pnia. Idealne pierwotne normy, do których przylgnęli pierwsi legendarni władcy Polski, wiązał Jasienica z szerszą europejską całością. Już więc w poglądach, które wyłożył w pierwszej fazie swojej twórczości, można odnaleźć antytezę Wschodu i Zachodu - co z powodów, o których będzie szerzej w dalszej części artykułu, wiązało się z forowaniem interpretacji godzącej w samo jądro historiozofii mającej legitymizować istniejący w kraju porządek społeczno-polityczny.

Antyteza Wschodu i Zachodu stanie się wyraźniej widoczna w tomach poświęconych Rzeczypospolitej Obojga Narodów. W odniesieniu do poglądów z pierwszej fazy twórczości, których jądro koncentrowało się wokół

${ }^{48}$ A.F. Grabski, Myśl historyczna polskiego oświecenia, Warszawa 1976, s. 17-45.

${ }^{49}$ A. Wierzbicki, Historiografia polska doby romantyzmu, Wrocław 1999, s. 307-336. 
apologii Polski piastowskiej i krytyki Polski jagiellońskiej, należy raczej powiedzieć, iż komponowały się one z „polityką historyczną" komunistycznej władzy. Ta ostatnia, szukając swojego uprawomocnienia, odwoływała się do idei Polski piastowskiej, widząc w niej historyczny drogowskaz odsłaniający prawdziwie „polskie drogi”. Oddajmy głos historykowi: „Tradycja piastowska podsuwała dobre rozwiązania. Po pierwsze, nie prowadziła do apoteozy ładu istniejącego przed samą rewolucją. Po drugie, odsyłała do najgłębszych korzeni polskości, do najczystszych polskich wartości, oznaczała powrót do słowiańskiej i ogólnonarodowej wspólnoty, do mitu stworzenia państwa polskiego [- - ]. Po trzecie, oznaczała odejście od koncepcji jagiellońskiej, czego wyrazem miało być ułożenie przyjacielskich stosunków ze Związkiem Radzieckim. Innymi słowy, pozwalała tworzyć mity legitymizujące nowy porządek" ${ }^{20}$.

Pomimo widocznej zbieżności z dążeniami władzy teza, iż poglądy Jasienicy całkowicie mieściły się w gorsecie uszytym z jej historyczno-ideologicznych oczekiwań, byłaby powierzchowna i zbyt daleko idąca. Przyjrzyjmy się drugiej fazie jego twórczości.

\section{Rzeczpospolita Obojga Narodów i rehabilitacja Polski Jagiellonów}

Lektura Polski Piastów i Polski Jagiellonów skłaniała do wniosku, iż zepchnięcie Polski z torów właściwego rozwoju, spowodowane przejęciem sterów nawy państwowej przez obcą dobrej piastowskiej tradycji politycznej dynastię, znajdzie swój tragiczny finał wraz z upadkiem Rzeczypospolitej w XVIII w. Po tak surowej krytyce, jaka spotkała unię w Polsce Jagiellonów, pierwszy tom Rzeczypospolitej Obojga Narodów bierze się do ręki z przeświadczeniem, iż jego treść musi niechybnie wyrażać pogląd wiążący kolejne niepowodzenia i katastrofy spadające na Rzeczpospolitą w XVII i XVIII stuleciu genetycznie z czasami jagiellońskimi. Wbrew jednak tym oczekiwaniom wina za te klęski spada tym razem niemal wyłącznie na barki Wazów i kontrreformacji, czasy jagiellońskie zaś doznają wyraźnej rehabilitacji.Zacytujmy jeden fragment będący komentarzem do polsko-litewskiejjagiellońskiej budowli.

Kraj, który ograniczył swych monarchów prawem, powierzył im władzę na podstawie umowy, ten kraj nie tylko żył, ale odnosił zwycięstwa w wojnach, wyraźnie szedł naprzód, rozwijał się. Rzezi i masowych prześladowań w nim nie było, obywatele jego bytowali w warunkach pod wielu względami godnych pozazdroszczenia. To było najważniejsze w polsko-litewskim doświadczeniu, wzbudzało na świecie żywe zainteresowanie. Demokratyczny (w porównaniu z innymi państwami)

${ }^{50}$ M. Zaremba, Komunizm, legitymizacja, nacjonalizm. Nacjonalistyczna legitymizacja władzy komunistycznej w Polsce, Warszawa 2001, s. 165. 
mechanizm Rzeczypospolitej funkcjonował, przysparzał swym kierownikom wielu kłopotów, ale okazywał się całkiem żywotny, miał przed sobą widoki. Myśliciele europejscy, których się uważa za wczesnych poprzedników Oświecenia, zyskiwali rzeczowy argument. [--] Trzeba z naciskiem podkreślić, że nasze własne i Europy dobro wcale nie wymagało zmiany struktury Rzeczypospolitej na jedynowładczą. Należało je tylko naprawić i wzmocnić, zgodnie z logiką, a polsko-litewskie doświadczenie mogło się kontynentowi przydaćc ${ }^{51}$.

Z kraju, który w wyniku unii zboczył z właściwej drogi, stała się Polska nagle awangardą najbardziej postępowych rozwiązań, drogowskazem dla całej Europy. Zrodzony z unii twór, będący terytorialnym wynaturzeniem, z dynastią, która oddała jego zasoby w służbę ideologii, sprawiając, iż wypadł z głównego nurtu dziejów Zachodu, dość nieoczekiwanie w kolejnych książkach Jasienicy okazywał się jednak żywotny z całkiem niezłymi widokami na przyszłość. Nie tylko nie zawierał w sobie zalążków przyszłego upadku (a jeśli, to w już nieporównanie mniejszej skali), ale stanowił świadectwo eksperymentu już całkiem udanego. Komentując polskie propozycje poszerzenia unii o Rosję z 1600 r., których na skutek niechęci strony rosyjskiej nie udało się zrealizować, Jasienica pisał:

Właściwy autor pomysłu scalenia historii środka i wschodu Europy to dwa wieki unii polsko-litewskiej. Myśl podobna mogła się zrodzić tylko w środowisku nawykłym do wielowątkowej kultury, pojmującym słowo „ojczyzna” w sposób niezaściankowy. Wśród ludzi, którzy odziedziczyli a nie wynaleźli! - przekonanie, że z wczorajszym wrogiem można się dziś dogadać, a jutro usadowić pod wspólnym dachem, że ogrom trudności można pokonać nie inaczej niż pracą pokoleñ ${ }^{52}$.

Jakaż zmiana tonu w spojrzeniu na unię! Trudno byłoby uzgodnić krytyczne oceny unii zawarte w Polsce Jagiellonów lub w Myślach o dawnej Polsce z jej retrospektywną rehabilitacją w serii poświęconej Rzeczypospolitej Obojga Narodów. Dyspozycja do szukania porozumienia z wczorajszym wrogiem była wyrazem wysokiej kultury politycznej. Poczęta w łonie państwa Jagiellonów, przetworzona dzięki praktyce w tradycję stanowiła trwałe osiągnięcie wystawiające jak najlepsze świadectwo unijnemu eksperymentowi.

Niezwykle interesujący jest przy tym obraz Rosji,jaki wyłania się z tych samych akapitów, które gloryfikują unię i Rzeczpospolitą Obojga Narodów.

${ }^{51}$ P. Jasienica, Rzeczpospolita Obojga Narodów. Srebrny Wiek, Warszawa 1967, s. $149-150$.

${ }^{52}$ Ibidem, s. 244. 
Jasienica pisał: „Legację, która przywiozła takie propozycje, gospodarze szczelnie odseparowali od świata, strzegli każdego jej kroku, traktowali niechętnie i podejrzliwie" ${ }^{53}$.Jak różne od sposobu myślenia reprezentantów polsko-litewskiego państwa były przekonania gospodarzy. Otwartość cechująca tych pierwszych obnażała ciasnotę horyzontów tych ostatnich. „W roku 1600 tylko jedna z układających się na Kremlu stron rozporządzała doświadczeniem, nie truchlała przed zuchwałym nowatorstwem, gotowa była próbować. Druga nie miała za sobą eksperymentu, kurczowo się trzymała dróg starych, które poprzez wszystkie zdeptane pergaminy mirów wieczystych musiały zaprowadzić nie gdzie indziej, jak na pola bitew" 54 .

W wywiadzie udzielonym „Tygodnikowi Powszechnemu” w 1965 r. Jasienica w ten oto sposób odnosił się do problemu tolerancji religijnej w monarchii jagiellońskiej:

Pisze się o tolerancji w epoce Jagiellonów, tłumaczy się ją jednak jako wynik letniości ideowej. Olbrzymie nieporozumienie! Zrodziło ją samo życie, fakt, że Rzeczpospolita składała się z kilku narodów i kilku wyznań. Nikt nie wątpił, że religijność stanowi podstawę wszelkiego porządku, ale dawano swobodę wszystkim tejże religijności formom i wyrazom. Tego rodzaju koncepcje pełniły u nas w XVI wieku funkcje państwowego wyznania wiary. Uświadomiono to sobie w pełni, więcej rozumiano, że tolerancja różni Rzeczpospolitą od całego pozostałego kontynentu europejskiego ${ }^{55}$.

Pogląd głoszący ideową letniość polskiego katolicyzmu, który w 1965 r. Jasienica uznał za olbrzymie nieporozumienie, w 1960 r. był, jak się zdaje, przez niego całkowicie podzielany. W Polsce Piastów pisał on bowiem:

Polacy są narodem katolickim, ale ich stosunek do wiary polega na uczuciu i przywiązaniu do tradycji. [- - ] Przyczyn tego stanu rzeczy jest na pewno wiele. Kto wie jednak, czy u samych podstaw zjawiska nie leży ów niezbity fakt, że przez tyle wieków istniały u nas dwie wiary rodzima, polska oraz ta druga, przybyła z daleka, mająca formy ustalone i niezmienne, a przemawiająca $w$ dodatku po łacinie. Było dość czasu, by w krew narodu weszło przyzwyczajenie, że ową łacińską religię należy przyjąć i pokochać, ale dociekać jej istoty nie ma potrzeby ${ }^{56}$.

${ }^{53}$ Ibidem.

${ }^{54}$ Ibidem, s. 245.

${ }^{55}$ Rozmowa z Pawłem Jasienica. Rozmowę przeprowadził Wiesław Paweł Szymański, „Tygodnik Powszechny" 1965, 19.

${ }^{56}$ P. Jasienica, Polska Piastów, Warszawa 1960, s. 217-218. 
Zarzut, który wcześniej formułował wobec Jagiellonów, posądzając ich o oddanie polityki w służbę ideologii i zerwanie z rozsądną praktyką Piastów, przenosił teraz wyraźnie w czasy późniejsze. Za degenerację ustrojową państwa nie odpowiadali już Jagiellonowie, lecz władcy z dynastii Wazów. Do rozregulowania niewątpliwie bardzo delikatnego organizmu, jakim była szlachecka Rzeczpospolita, przyczynił się Zygmunt III. Nie rozumiał i nie lubił Polaków. Otaczał się obcymi. Prowadził politykę dynastyczną sprzeczną z polską racją stanu. To on „,wymazał ze swej pamięci najlepszą z Jagiellońskich tradycji politycznych - sojusz króla ze średnią i małą szlachtą" ${ }^{57}$. Przede wszystkim jednak oddanie aparatu państwowego do realizacji zadań wybitnie ideologicznych wiązało się z poparciem, jakiego Zygmunt udzielił kontrreformacji. Tej ostatniej nie szczędził Jasienica słów krytyki. „Pod jej wpływem - pisał - szlachta polska zaparła się polskiej historii. Odrzuciła wielowiekowe piastowskie i jagiellońskie tradycje powściągliwości i umiaru we wszystkim, co dotyczy religii" ${ }^{58}$. W wieloetnicznym i wielowyznaniowym państwie polityka dyskryminacji religijnej była zwyczajnie zabójcza. Ideologiczne uprzedzenia sprawiły, iż Zygmunt odegrał fatalną rolę na „pamiętnym sejmie” w 1606 r. Przed sejmem tym rysowała się szansa przeprowadzenia istotnych reform. Nie doszedł on jednak do skutku w wyniku działań „oczadziałego" króla, który nie akceptował uchwał gwarantujących między innymi prawną ochronę niekatolików przed tumultami religijnymi.

Unicestwienie sejmu stało się paliwem dla rokoszu Zebrzydowskiego. Król wygrał w polu, ale z planów reform musiał się wycofać. Rokosz, zdaniem Jasienicy, zwichnął rozsądną opozycję i na dobre zatruł stosunki między społeczeństwem a władzą. Odtąd nieufność wobec wszelkich planów reform przybrała patologiczne rozmiary, uniemożliwiając skuteczną naprawę Rzeczypospolitej w przyszłości. „Nie da się zaprzeczyć - pisał - że weszliśmy wtedy na drogę gwałtownymi zakosami wiodącą coraz to niżej i niżej”59. „Sługa doktryn”, jak nazywał Jasienica Zygmunta, prowadził również katastrofalną politykę zagraniczną. Zamiast opowiedzieć się w wojnie trzydziestoletniej przeciwko Habsburgom, utrwalając rozbicie państw niemieckich, sprawił, iż „braliśmy na siebie dla nich przeznaczone uderzenia Szwedów oraz przychylnych obozowi protestanckiemu Turków" ${ }^{60}$. Zaangażowanie króla w dymitriady nastąpiło wbrew odczuciom przygniatającej większości szlacheckiej braci, potęgując w niej „zakamieniały pacyfizm”, który „nabrał cech alergii”. Podsumowując panowanie Zygmunta

\footnotetext{
${ }^{57}$ Idem, Rzeczpospolita Obojga Narodów. Srebrny, s. 256-257.

${ }^{58}$ Idem, Polska anarchia, s. 107.

${ }^{59}$ Ibidem, s. 73.

${ }^{60}$ Idem, Rzeczpospolita Obojga Narodów. Srebrny, s. 326.
} 
i Władysława, Jasienica stwierdzał: „Zygmunt III zaprzęgał wielowyznaniowy kraj do służb misjonarskich, jego bezcenny dorobek, utrwaloną już harmonię wewnętrzną bez skrupułów niszczył. Władysław IV hołdował swojej własnej osobie i sławie. Obaj w rozmaity sposób, lecz z jednakim skutkiem, rozpraszali istniejące zasoby materialne" ${ }^{11}$. Szkodliwe panowanie Wazów jeszcze raz przeciwstawione zostało „utrwalonej harmonii wewnętrznej” będącej wszak dziełem epoki Jagiellonów. Krytyce tych pierwszych towarzyszyła rehabilitacja drugich.

Początkowo Jasienica jasno artykułował pogląd, iż epoka Jagiellonów oznaczała anomalię w rozwoju dziejowym Polski i rozbrat z Zachodem. W tomach poświęconych Rzeczypospolitej Obojga Narodów prawa polityczne przyznane innowiercom w czasach jagiellońskich świadczyły o tym, iż Polska wyprzedziła pozostałe państwa europejskie pod względem rozwiązań ustrojowych. Błędy Wazów dopiero sprawiły, iż związek Polski z Zachodem został zerwany. To wówczas Obydwa Narody odstały od Europy, „bo zatrzymały się w miejscu, uznały swój wewnętrzny porządek i patronującą mu ideologię za nienaruszalny ideał. Bezwładna jałowa Rzeczpospolita stała się dziwolągiem na kontynencie, wśród państw i społeczeństw nieustannie poszukujących świeżych myśli, form i rozwiązań. Polska zapomniała o swoich własnych, średniowiecznych i renesansowych tradycjach dotrzymywania kroku i wybiegania naprzód"62.

Powrót do wspólnoty europejskiej nastąpił, zdaniem Jasienicy, w połowie XVIII w. wraz z recepcją idei oświecenia. Ówczesny przewrót umysłowy oznaczał ponowne włączenie się w najbardziej postępowy nurt dziejów Starego Kontynentu. Nie mógł już jednak wpłynąć na zachowanie niepodległości. O jej utracie przesądziła już bowiem wojna północna, z której wyszła Polska jako państwo całkowicie zdane na łaskę Rosji. Co więcej, proces pozytywnej przemiany świadomości społecznej nie tylko był obojętny z punktu widzenia ratowania suwerenności, lecz walnie przyczynił się do jej utraty. Pchnął państwa ościenne - które ani myślały biernie przyglądać się procesowi reform w Rzeczypospolitej - do aktu rozbiorów. Odrodzenie umysłowe ostatecznie przypieczętowało katastrofę polityczną:

W połowie XVIII stulecia - pisał Jasienica - po raz drugi wystartowaliśmy do czynnego udziału w historii Europy i jej kultury, w którym to twierdzeniu nie ma przenośni. $Z$ dokonanej wtedy wewnętrznej, obywatelskiej metamorfozy wywodzą się późniejsze reformy polityczne, wśród których zdarzały się i nowatorstwa w skali światowej, i pęd ku społecznym, nowa literatura i nauka. Nasi osiemnastowieczni odnowiciele zaczerpnęli tchu

${ }^{61}$ Ibidem, s. 490.

${ }^{62}$ Idem, Rzeczpospolita Obojga Narodów. Dzieje agonii, Warszawa 1972, s. 175. 
na Zachodzie, ich prace krajowe stopniowo uleczały z paraliżu wszystkie dziedziny życia społecznego, były dla nich łaską, lekiem zbawiennym. Błogosławione wysilenia jedną tylko rzecz musiały narazić na kryzys wręcz śmiertelny, mianowicie samo państwo ${ }^{63}$.

Z oceny przewrotu umysłowego wykluczył Jasienica kontekst związany z potęgowaniem zdolności kraju do ratowania politycznej niezawisłości. Rzec można, iż w epoce oświecenia dokonała Rzeczpospolita ekspiacji za grzechy obciążające jej dziejowe konto, by z czystym sumieniem wydać w 1795 r. swoje ostatnie tchnienie.

W tomach poświęconych Rzeczypospolitej Obojga Narodów uwzględniał Jasienica do pewnego przynajmniej stopnia wyniki badań nad dziejami społeczno-gospodarczymi. Powołując się na ustalenia „dzisiejszych ekonomistów", wskazywał na kurczenie się rynku wewnętrznego, na związaną z tym pogarszającą się dolę chłopa, na spadek wartości pieniądza itd. Kryzys gospodarczy z pierwszej połowy XVII w. stawał się jednym z elementów wpływających na stopniową utratę politycznej mocy Rzeczypospolitej. Podkreślić wszak należy, że interpretacja Jasienicy była biegunowo odmienna od tego, co proponowano w ramach sztampowego marksizmu. Dla autora Polski Jagiellonów to nie kryzys gospodarczy determinował kłopoty polityczne, lecz odwrotnie - to błędne decyzje polityczne sprowadzały na kraj kłopoty gospodarcze ${ }^{64}$.

W kontekście wzmiankowanego wyżej kryzysu gospodarczego Rzeczypospolitej wymownie przedstawia się porównanie poglądów, które Jasienica wyartykułował w opublikowanym w 1962 r. tekście na temat polskiej anarchii, z poglądami wyłożonymi w przytoczonym już wywiadzie dla „Tygodnika Powszechnego” z 1965 r. W 1962 r. wyłączną winą za zanarchizowanie Rzeczypospolitej obarczał dwóch ostatnich Jagiellonów, którzy mieli podjąć fatalną w skutkach decyzję sprawowania władzy przy poparciu magnaterii. W udzielonym wywiadzie trzy lata później Jasienica w ogóle nie wspominał o Jagiellonach, za wybór „arystokratycznej doktryny rządzenia" obwiniał Zygmunta Wazę, wskazując zarazem na kryzys gospodarczy jako na dodatkowy element pogłębiający trudne położenie kraju ${ }^{65}$.

Wskazana wyżej niewątpliwa rehabilitacja unii z Litwą w tomach poświęconych Rzeczypospolitej Obojga Narodów nie oznaczała zarazem, iż w twórczości Jasienicy nie było istotnych wątków konsekwentnie podtrzymywanych we wszystkich powstałych w różnych okresach książkach.

\footnotetext{
${ }^{63}$ Ibidem, 270-271.

${ }^{64}$ Idem, Rzeczpospolita Obojga Narodów. Srebrny, s. 349-350.

${ }^{65}$ Rozmowa z Pawłem Jasienica.
} 
Jakkolwiek w czasach jagiellońskich udało się wprowadzić wewnętrzną harmonię w gmach polsko-litewskiego państwa, to przecież realizacja tego zadania spoczywała głównie na barkach strony polskiej. Urzeczywistnione w szesnastowiecznej Polsce wartości polityczne, stawiające kraj $\mathrm{w}$ awangardzie cywilizacyjnego postępu, były bez wątpienia dziełem nieporównanie wyżej kulturalnie stojących Polaków, którzy nieśli cywilizację na Wschód. W wypełnieniu tej misji napotykali zresztą stałe przeszkody. Nie mogła zostać uwieńczona pełnym sukcesem, a to $z$ tego względu, iż niezwykle trudno było zaszczepić nowoczesne reguły kulturze, która do nich nie dojrzała. Dopóki państwo jako całość charakteryzowało się względną spoistością, głównie dzięki wysiłkowi Polaków, brak głębokiego, organicznego przyswojenia przez wschodniego partnera przeniesionych z Polski urządzeń ustrojowych udawało się zatrzeć. Degeneracja ustrojowa Rzeczypospolitej obnażyła jednak w pewnym stopniu naskórkowość polskich dokonań na Wschodzie. Nawiązując do wydarzeń z początków XVIII stulecia, Jasienica pisał:

Polskie swobody stanowe przeszczepione zostały na grunt litewski poniekąd sztucznie, zarządzeniami monarchów, nie były w Wielkim Księstwie wynikiem ewolucji stosunków miejscowych. Mariaż zaawansowanego importu z prymitywnym podglebiem zrodził zjawiska monstrualne. Te same zasady, które na zachód od Bugu stworzyły demokrację szlachecką, na wschód od niego pomogły wyrosnąć niebywale groźnej oligarchii ${ }^{66}$.

Opinię, że „Polska do unii przez cały czas dopłacała”, powtarzał Jasienica konsekwentnie we wszystkich swoich pracach. Na szczególne podkreślenie zasługuje fakt, iż w przytoczonej wyżej wypowiedzi zawarł Jasienica również historyczną antytezę Wschodu i Zachodu.Jest oczywiste, że określenie „prymitywne podglebie”, które charakteryzowało Litwę, obejmowało swym zasięgiem również Rosję. Niewątpliwie eksponowanie cywilizacyjnych różnic między Polską a Rosją nie mieściło się w ówczesnym kanonie historiograficzno-politycznej poprawności. Umieszczenie dziejów Polski wewnątrz historiozoficznego schematu teorii formacji oznaczało włączenie ich w ten sam nurt rozwoju historycznego, którym biegły dzieje Rosji. Budowa socjalizmu w Polsce po II wojnie światowej oznaczała podążanie tym samym szlakiem dziejowego postępu, którym Rosja zmierzała już pewnie od czasów rewolucji październikowej. Sprowadzenie dziejów obu państw do wspólnego historiozoficznego mianownika stanowiło uzasadnienie łączącego ich współcześnie sojuszu, jak również pełniło funkcję legitymizującą wprowadzany w obu krajach ustrój. Interpretacja akcentująca

${ }^{66}$ P. Jasienica, Rzeczpospolita Obojga Narodów. Dzieje agonii, s. 75. 
głębokie cywilizacyjne różnice dzielące Rzeczpospolitą i jej wschodniego sąsiada burzyła historiozoficzny szkielet konstytuujący stalinowsko-marksistowskie ujęcia polskiej przeszłości. W tym właśnie punkcie zasłużył sobie Jasienica na miano historiograficznego dysydenta.

\section{Twórczość Pawła Jasienicy w oczach krytyków i komentatorów w dobie Polski Ludowej}

\section{Między marksizmem a „personalizmem”}

Niejeden metodolog byłby szczerze zbudowany lekturą recenzji poświęconych kolejnym książkom Jasienicy. Omówienia te bowiem - wbrew przecież wcale nierzadkiej praktyce - nie koncentrowały się na wytykaniu potknięć faktograficznych, demaskowaniu błędów w przypisach lub w datacji poszczególnych wydarzeń. Prace Jasienicy prowokowały recenzentów do dyskusji eksponujących fundamentalne kwestie teoretyczno-metodologiczne. W tym względzie pierwszoplanowe znaczenie zyskiwały wypowiedzi badające prawomocność i metodologiczną wartość stanowiska określanego mianem ,personalizmu”, którego odzwierciedleniem miała być właśnie twórczość Jasienicy. W jej ramach „personalizm” wiązał się z przypisywaniem wyjątkowej dziejotwórczej roli przedstawicielom panującej dynastii. W opinii recenzentów, głównie profesjonalnych historyków, podejście to odtwarzało wzory bardzo już archaicznej historiografii, odstającej od jej zmodernizowanych wersji przyswajających z powodzeniem osiągnięcia innych dziedzin wiedzy. W nich bowiem rozszerzenie pola obserwacji o zjawiska masowe, o procesy społeczne i gospodarcze wiązało się nierozerwalnie z krytyką ujęć tradycyjnych, w których bieg dziejów pozostawał pod wyłącznym nadzorem jednostek, zazwyczaj głów panujących rodów.

I choć w Polsce Ludowej znakiem firmowym modernizacji historiografii był marksizm, a interpretacje uznane za wyrastające z dojrzalszej metodologicznie alternatywy były nim inspirowane, to krytyka Jasienicowego „personalizmu” odwoływała się do horyzontu metodologicznego wykraczającego poza sam tylko materializm historyczny. „Nie trzeba być marksistą - pisał w recenzji z Polski Piastów Juliusz Bardach - by widzieć we właściwym świetle miejsce jednostki w procesie dziejowym" ${ }^{67}$. Sięgając daleko w głąb tradycji historiograficznej, można było odnaleźć dzieła, które skutecznie przezwyciężały ujęcia oceniające działania władców w izolacji od ich społecznych i gospodarczych determinant. Bardach przywoły-

${ }^{67}$ J. Bardach, Czy dzieje Piastów, „Polityka” 1960, 34 (fragmenty tej recenzji zostały również zamieszczone w „Kwartalniku Historycznym” 68, 1961, 1, s. 179-183). 
wał przykład Stanisława Smolki, świetnego, jak pisał, historyka i zarazem... krakowskiego konserwatysty, który „potrafił ukazać wzajemny stosunek sił społecznych działających w danej epoce do jednostki - bez wątpienia wybitnej - ale stającej w poprzek ewolucji, a więc skazanej na klęskę" ". Celina Bobińska w recenzji z Polski Jagiellonów wskazywała, iż w dziele Jasienicy „przybrane w atrakcyjną szatę walki o wartości narodowe przeciwko schematyzmowi marksistów występują tu bardzo stare rekwizyty woluntarystyczne"69. Po wsparcie - niechybnie w trosce o zobiektywizowanie swojej oceny - sięgała do dorobku ideowych przeciwników, pisząc „Toć 150 lat temu stary liberał burżuazyjny Thierry, walcząc z wówczas już przestarzałym heroistycznym ujęciem historii na rzecz historii w gruncie rzeczy integralnej, pisał, że dotychczas u historyków scenę zajmuje tylko kilka uprzywilejowanych postaci". Do wniosku, iż daleko idące uwolnienie władzy i polityki od podłoża społecznego jest nieuzasadnione, skłaniały uwagi poczynione przez Janusza Tazbira na marginesie Ostatniej z rodu, pracy, którą Jasienica poświęcił Annie Jagiellonce. Tazbir podkreślał, iż w pełni podziela przekonanie autora, iż znaczenie i autorytet „ostatniej z rodu” płynęło nie tyle z jej osobistych walorów, ile z przywiązania ogółu szlacheckiego do dynastii oraz z szacunku, jaki ów ogół żywił dla pewnych form ustrojowych. To jednak oznaczało - pisał Tazbir - że „nie tyle jednostka, ile jej kult odegrał twórczą i doniosłą rolę w dziejach"70.

Krytyka metodologicznego kształtu książek Jasienicy karmiła się marksizmem. Często też zawierała prezentację alternatywnej oferty interpretacyjnej wyraźnie do marksizmu nawiązującej. W tym względzie odzwierciedlała dwa, obecne w historiografii krajowej, praktyczne wcielenia marksistowskiej metodologii. Jedno, wyrastające $\mathrm{z}$ - jak się wydaje - autentycznego, a zarazem stosunkowo elastycznego uznania dla ogólnej teorii rzeczywistości, eksponującej znaczenie sfery produkcji i wymiany dla ruchu dziejów, akcentującej dziejotwórcze znaczenie ogólnie pojętych interesów klasowych i uznającej, iż struktury gospodarcze czy ustrojowe nie są neutralne z punktu widzenia tych interesów. Takie podejście wiązało się z ogólnym ukierunkowaniem analiz historycznych, z promowaniem nowego katalogu pytań badawczych, z włączaniem w obszar zainteresowania historyków nowych, nie poddanych dotychczas badawczej eksploracji zagadnień, nie przesądzając zarazem o rezultatach prowadzonych badań. Drugie wcielenie było związane z promocją ściśle deterministycznego schematu, zgodnie z którym dzieje

\footnotetext{
${ }^{68}$ Ibidem.

${ }^{69}$ C. Bobińska, Poeta, Jasienica i historia, „Nowa Kultura” 1962, 13.

70 J. Tazbir, Piękny arras z Jagiellonami, ,Kultura” (Warszawa) 1965, 28.
} 
mają charakter prawidłowego procesu, a Polska Ludowa jawi się jako konieczne, pozytywne jego zwieńczenie.

W recenzji z Myśli o dawnej Polsce Benedykt Zientara chwalił Jasienicę za pokazanie, „w jak wielkie niebezpieczeństwa wplątała się Polska przez unię z Litwą"71. Nie godził się jednak z tezą, że unia ta była wynikiem w sumie przypadkowych okoliczności, że, jak chciał Jasienica, doszło do niej, ponieważ Ludwik Węgierski nie doczekał się męskich potomków. Zdaniem Zientary, ten dynastyczny fakt zadecydował tylko o układzie w Krewie. Układ ów nie zaprowadziłby jednak do powstania wielonarodowej Rzeczypospolitej,gdyby w grę nie wchodziły czynniki o charakterze społeczno-gospodarczym. Jeśli, jak podkreślał Zientara, pomimo wielu prób i okazji do zerwania unii, ze strony polskiej czyniono tak duże wysiłki, aby unię utrzymać, to dlatego, iż „odpowiadało to interesom i tendencjom ekspansywnym rządzącej grupy feudałów". W przyjętej przez Zientarę optyce dziejów politycznych nie dawało się wypreparować ze społeczno-gospodarczego podłoża.

Przeciwko umieszczaniu polityki w takiej społeczno-gospodarczej próżni protestował zdecydowanie Bardach. Nawiązując do uwag Jasienicy wyrażającego żal, iż następcy Kazimierza Wielkiego stali się już tylko królami szlachty, stwierdzał: „wygląda to tak, jakby od woli króla w dobie feudalizmu zależało, jakie warstwy i stany będzie on reprezentował"72. Przykład szczególnie kuriozalnego wyodrębniania polityki z całości społeczno-gospodarczego bytu, któremu towarzyszyły równie wątpliwe oceny historyczne, odnajdował ten recenzent w następującym zdaniu: „,okrutne zniszczenie niektórych miast i dzielnic było tylko doraźnie ważne. Od dawna całkiem dobrze zagospodarowany kraj potrafił szybko odrobić straty. Prawdziwa klęska to śmierć Henryka Pobożnego i zatrata planów zmierzających do zjednoczenia państwa pod berłem Piastów śląskich”. „Skoro wszystko - brzmiał komentarz Bardacha - jest skutkiem działania monarchy, to jego śmierć przedwczesna jest największą klęską, gorszą od zniszczenia kraju". Krytyka Bardacha miała podwójny charakter - ontologiczny i aksjologiczny. Ontologiczny, gdyż Jasienica ignorował związek między szansami osiągania celów politycznych (zjednoczenie) a stanem sfery gospodarczej i społecznej. Z przytoczonego zdania wynikało bowiem, iż zniszczenie kraju było z punktu widzenia projektów zjednoczenia rzeczą obojętną, liczyła się wyłącznie wola i zamiary władcy, które mógł on realizować właśnie niezależnie od gospodarczej kondycji domeny, którą władał. Aksjologiczny, gdyż,jak można się domyślać, ocena działań władzy musiała brać pod uwage jej zdolność do przeciwdziałania siejącym spustoszenie najaz-

\footnotetext{
${ }^{71}$ B. Zientara, Myśli nad „Myślami”, „Mówią Wieki” 1961, 5, s. 28.

${ }^{72} \mathrm{~J}$. Bardach, op. cit.
} 
dom. Polityczne zjednoczenie nabierało aksjologicznej mocy wyłącznie ze względu na związaną z nim przewidywaną poprawę losu i bezpieczeństwo szerokiego grona poddanych. Nieuzasadnione rozluźnienie związku między tym, co społeczne, a tym, co polityczne, skutkowało równie nieuzasadnionym rozluźnieniem związku między polityką a aksjologicznym zakorzenieniem, w świetle którego powinna była być ona oceniana. Fakt, iż Jasienica w jednym zdaniu lekceważył gospodarcze, społeczne i psychologiczne straty (zubożenie, spadek demograficzny, utrata bliskich, związana z tym trauma itp.) wynikające $\mathrm{z}$ najazdu, eksponując wizję zjednoczenia politycznego, pokazywał, iż wpisany w jego twórczość namysł nad przeszłością i światem polityki nie zawsze mieścił się w rygorach wolnego od metafizycznych naleciałości racjonalizmu. Skoro bowiem zjednoczeniu nie towarzyszył wzgląd na dobro mieszkańców, to stawało się ono wyłącznie abstrakcyjną ideą.

W podobnym duchu wypowiadał się Bardach w dyskusji nad przyczynami anarchii w szlacheckiej Polsce, zainicjowanej artykułem Jasienicy opublikowanym w 1962 r. w „Przeglądzie Kulturalnym”73. W dyskusji tej szczególnie wyraźnie zaznaczyło się zderzenie Jasienicowego „personalizmu" z marksistowskimi kontrpropozycjami. Stanowisko Jasienicy było bowiem na wskroś „personalistyczne”. Wyłączną winą za zanarchizowanie szlacheckiej Rzeczypospolitej obarczał Jasienica dwóch ostatnich Jagiellonów, którzy zbłądzili, wybierając arystokratyczną doktrynę rządzenia, czym ostatecznie zrywali z dobrymi piastowskimi tradycjami władzy upominającej się o dobro wszystkich, nie tylko szlacheckich, poddanych. I w tym przypadku nie wykazał się Jasienica metodologiczną wrażliwością, ujmując władzę „w oderwaniu od socjalnych uwarunkowań”. Tymczasem ta, jak utrzymywał zabierający głos w tej dyskusji Bardach, zawsze spoczywa w ręku klas bądź warstw społecznych, które „wykorzystują ją do swoich celów, dla zagwarantowania swoich praw i przywilejów, dla umocnienia swoich pozycji ekonomicznych i politycznych"74. Oferując alternatywne wyjaśnienie genezy polskiej anarchii, odwoływał się do obiektywnych struktur społecznych i gospodarczych, które tłumaczyły zarówno rozwój anarchii, jak i odrębny w stosunku do krajów Zachodu historyczny rozwój Polski. To niezwykła liczebność szlachty, stanowiącej aż 10 procent całej ludności, sprawiała, iż nie musiała ona szukać sojuszu z królem, a nawet mogła dążyć do jego podporządkowania. Potrafiła też usunąć z życia politycznego miasta, pozbawiając mieszczan „,najbardziej dochodowych gałęzi handlu, skupiając w swym ręku eksport zboża

\footnotetext{
${ }^{73}$ P. Jasienica, Polska anarchia, ,Przegląd Kulturalny” 1962, 10.

${ }^{74}$ J. Bardach, Polska anarchia czy anarchia w Polsce, ,Przegląd Kulturalny” 1962, 12.
} 
i innych płodów gospodarstwa wiejskiego oraz sprowadzając z zagranicy bez cła towary na swoje potrzeby". Bardach wskazywał, iż powiązanie gospodarki folwarczno-pańszczyźnianej i poddaństwa chłopów ze szlacheckim monopolem handlu zewnętrznego, z jej polityczną dyktaturą doprowadziło do ostatecznego pognębienia miast i stało się „czynnikiem, który w XVII wieku przywracał charakter naturalny gospodarki polskiej prowadząc do gospodarczej autarkii poszczególnych dóbr zwanych w ówczesnej terminologii "państwami»"75. Ta gospodarcza atomizacja idąca ręka w rękę z brakiem silnej scentralizowanej władzy stanowiła żyzną glebę dla rozwoju anarchii. W powyższym ujęciu anarchia była zatem skutkiem przeobrażeń zachodzących w bardziej pierwotnej sferze społeczno-gospodarczej, która wpływała i determinowała charakter polityki i kierunek przemian ustrojowych. Mówiąc krótko, baza determinowała nadbudowę.

Twardą marksistowską alternatywę wobec poglądów Jasienicy wyjaśniających źródła anarchii w Polsce przedstawił ekonomista Jan Dąb-Kocioł. „Anarchia - pisał - przejawia się w nadbudowie społecznej,jednakże rodzi się w bazie produkcyjnej. Źródłem anarchii polskiej nie była ani wolna elekcja, ani liberum veto, ani mity szlacheckie, ani «umiłowanie wolności». Anarchia zrodziła się w gospodarce Polski szlacheckiej i stąd przenikała do życia politycznego, oddziaływając na kształtowanie się praw, obyczajów, moralności i kultury"76.

Przywiązaniu do stalinowskiego marksizmu dała wyraz w recenzji z Polski Jagiellonów Ewa Maleczyńska. Wbrew Jasienicy, który w unii z Litwą chciał widzieć wydarzenie o charakterze wybitnie politycznym, pozbawione szerszego społeczno-gospodarczego podłoża, Maleczyńska wskazywała, iż unia była efektem klasowych dążeń feudałów reprezentujących siły stare, ,popychane przede wszystkim przez charakterystyczny dla nich głód wielkich obszarów ziemskich". One to właśnie, twierdziła, miały dążyć do inkorporacji Litwy czy „,bodaj do zapewnienia rządów na Rusi Halickiej” i były zarazem „całkowicie obojętne dla sprawy mieszczańskiego, gęsto zaludnionego Śląska". O walce starego z nowym tak pisała:

I tu dochodzimy do sedna rzeczy, do ideowo-politycznej funkcji szkiców Jasienicy, którą pełnią niezależnie nawet być może od założeń autora. Otóż synteza stosunków polsko-litewskich jaką daje Jasienica jest nie do przyjęcia, a jest tym niebezpieczniejsza, że jest zawoalowana niewątpliwą słusznością i postępowością pewnych szczególnych ujęć. $\mathrm{W}$ istocie rzeczy jednak wywody Jasienicy sugerują czytelnikowi nacjonalistyczno polski punkt widzenia [--]. Oczywiście, że w czterna-

\footnotetext{
${ }^{75}$ Ibidem.

${ }^{76}$ J. Dąb-Kocioł, Ani z soli, ani z roli, ,Przegląd Kulturalny” 1962, 17.
} 
sto i piętnastowiecznych feudałach polskich nie tkwiło żadne immanentne zło dlatego właśnie, że byli feudałami. Sąd taki zresztą byłby nie marksistowski a metafizyczny. Ale jest niezaprzeczalne, że jak każda klasa czy warstwa, feudałowie polscy mieli swe własne interesy wyrosłe na podłożu ekonomicznym i one to w ostatniej instancji - znów jak każdej klasie - dyktowały im postępowanie. Jako warstwa rządząca subiektywnie identyfikowali często interes własny z interesem Polski [- ]. Subiektywnie też w poczuciu własnym mogli być nawet żarliwymi patriotami. A obiektywnie? Obiektywnie były okresy, w których interes feudałów pokrywał się rzeczywiście z interesem kraju. Tak było niewątpliwie w Polsce piastowskiej, za czasów państwa wczesnofeudalnego, kiedy postęp wyrażał się właśnie w gruntowaniu feudalizmu. Inaczej jest jednak na przełomie XIV i XV wieku. Narastają nowe siły społeczne, przede wszystkim w miastach; prą do centralizacji, do walki $\mathrm{z}$ anarchią feudalną, córką feudalnego rozdrobnienia, wynoszą na powierzchnię życia hasła narodowe. W każdym kraju narasta teraz wewnętrzne zróżnicowanie, zaostrza się walka sił starych i nowych. $\mathrm{Na}$ jednym biegunie monarchia, miasta i część związanej z produkcją towarowo-pieniężną „nowej szlachty”; na drugim biegunie stary, oparty głównie o masowe świadczenia chłopskie i wielkie obszary ziemskie świat feudalny [- - ] ta walka starego z nowym przenika w dziesiątkach wariantów każdy kraj [- - ] są to wszystko truizmy [- - ] ale niestety te truizmy trzeba było tu przypomnieć, skoro Jasienica zupełnie nie dostrzega podstawowych cech okresu, o którym pisze ${ }^{77}$.

Spojrzenie na feudalizm z perspektywy idei postępu odsyłało do historiozoficznego schematu teorii formacji. Powiązanie różnych faz feudalizmu z postępowym i niepostępowym nurtem dziejów było częścią marksistowsko-stalinowskiej millenarystycznej historiozofii i jako takie zawierało milczacce odniesienie do socjalistyczno-komunistycznej utopii, stając się jednocześnie ideologiczną apologią Polski Ludowej. W tym też tkwiła, powiedzmy parafrazując Maleczyńską, ideowo-polityczna funkcja jej recenzji.

Interpretacje akcentujące ontologiczne powiązanie różnych sfer rzeczywistości, a z takim powiązaniem mamy do czynienia w przypadku marksizmu, rozsadzały mityczny ładunek Jasienicowego ujęcia dziejów Polski. Widać to wyraźnie w poświęconych anarchii uwagach Aleksandra Gieysztora. „Myli się głęboko Jasienica - pisał Gieysztor sądząc, że z rozważań o przejawach anarchii w historii Polski trzeba wyłączyć wieki średnie. Jak w każdej walce o władzę i w każdym jej podziale między grupy społeczne, tak też w układzie politycznym Polski pia-

${ }^{77}$ E. Maleczyńska, O słuszna syntezę czasów jagiellońskich, „Nowa Kultura” 1962, 4. 
stowskiej było miejsce na ścieranie się tendencji centralizujących strukturę państwową z odśrodkowymi" ${ }^{78}$. W dobie średniowiecza tendencje odśrodkowe wystąpiły najsilniej w dobie rozbicia dzielnicowego. Gieysztor podkreślał, iż wśród historyków średniowiecza zdobywała sobie uznanie dialektyczna interpretacja rozdrobnienia feudalnego, ,gdzie objawom anarchii politycznej, towarzyszyć potrafi burzliwy rozwój gospodarczy i różnicowanie się układu społecznego prowadzące z kolei do ukrócenia partykularyzmów lokalnej władzy i do odbudowy, już na innych podstawach społeczno-gospodarczych, zjednoczonego Królestwa Polskiego" "79 . W ujęciu Gieysztora pomyślne rozstrzygnięcia polityczne nie były wynikiem autonomicznych działań kolejnych przedstawicieli piastowskiej dynastii, których decyzje wyrastały z przywiązania do pierwiastkowych zasad praktyki politycznej ustanowionych ongiś przez legendarnych założycieli panującego w Polsce rodu. Genezy sukcesu odniesionego przez Łokietka i Kazimierza Wielkiego w realizacji dzieła ponownej konsolidacji kraju nie należało szukać w legendarnych początkach Polski. Był on wypadkową skomplikowanych procesów wykraczających poza sferę wąsko rozumianej polityki, których chronologiczne zakorzenienie z pewnością nie sięgało kilku stuleci wstecz. Ulokowanie przejawów anarchii również w czasach piastowskich sprawiało, iż epoka ta traciła swój mityczny immunitet. Przestawała być wydzieloną oazą, w której przywiązanie Piastów do pierwiastkowych zasad politycznych zapewniało krajowi możliwość skutecznej regeneracji po okresach głębokich kryzysów politycznych. Rzeczywistość polityczną kształtowała gra sił społecznych, wyjęta spod oddziaływania politycznych przykazań mitycznych ojców założycieli kraju nad Wisłą.

W recenzji z Polski Piastów opublikowanej w „Twórczości” $(1960,12)$ formułował Gieysztor uwagi, które wydobywały tkwiący w nich „mityczny potencjał" (choć kategoria mitu nigdzie w recenzji się nie pojawia). „Cóż to - pisał - za sugestywny, nowy, choć nie tak daleki od Matejki, poczet dynastii, ci zbóje i mordercy, gracze i asceci (tych było najmniej), gwałtownicy i rządziciele! Ale i szermierze ukochanej przez autora «myśli politycznej», wśród nich 12-letni urodzeni wodzowie i politycy, odważni jak mało kto, pobudliwi, dumni, okrutni i chytrzy (niech czyta kto nie wierzy s. 122!)"80. Opowieść podejmująca kwestię moralnych wyborów i dylematów głównych bohaterów przedstawionego przez Jasienicę dramatu, uwikłanych w ponadczasową walkę dobra ze złem, mogła liczyć na żywy

\footnotetext{
${ }^{78}$ A. Gieysztor, Anarchologia, ,Przegląd Kulturalny” 1962, 17.

${ }^{79}$ Ibidem.

${ }^{80}$ Przedruk kluczowych fragmentów z recenzji Polski Piastów Aleksandra Gieysztora: KH 68, 1961, 1, s. 181-183, tu 181.
} 
odzew współczesnego czytelnika, i to nie tylko dlatego, że - jak pisał Gieysztor - „problematyka władzy, jej socjologia, ocena szans powodzenia politycznego - wszystko to fascynuje nas na co dzień", ale również dlatego, iż w takich właśnie egzystencjalno-moralnych kategoriach odbierana i oceniana jest powszechnie polityka. Opowieść historyczna stawała się komentarzem do współczesności, zrozumiałym i angażującym szerokie audytorium. „Autor - podkreślał w recenzji Gieysztor - nie tylko próbuje wyjaśniać teraźniejszość przez przeszłość, ale przeszłość przez teraźniejszość". Historycy jednak - dodawał - wahają się nieraz w pójściu za Pawłem Jasienicą, ,,zarówno w jego uwspółcześnianiu historii, jak i jego uhistorycznianiu dnia dzisiejszego"81.

$\mathrm{Z}$ zagadnieniem niezwykłego społecznego rezonansu książek Jasienicy próbowała się zmierzyć również wspomniana już Bobińska. Inaczej jednak niż Gieysztor - dla którego zachowanie przeciętnego czytelnika przedkładającego personalistyczne ujęcia Jasienicy nad specjalistyczną literaturę, dorównującą często poziomem skomplikowania fizyce jądrowej (sformułowanie Gieysztora), było czymś do pewnego stopnia naturalnym - Bobińska włączała pracę społecznej świadomości w strukturę marksistowsko-stalinowskiego schematu, w którego ramach istniejące społeczne preferencje dotyczące historiografii były wyrazem klasowej niedojrzałości. Walka z nią była bez wątpienia obywatelskim obowiązkiem uczonego. Przeciwstawiając pisarstwo historyczne Jasienicy wspomnianej już idei historii integralnej, recenzentka pisała:

Wszystko to pięknie - powiedzą polemiści - ale naród czyta nie waszą historię integralną, lecz Jasienicę, zaspokajając w jego książkach pewne tęsknoty czytelnicze i ogólniejsze. [- - ] W żywej polskiej tradycji historycznej, podobnie jak i w tradycji każdego innego społeczeństwa, istnieją zarówno warstwy archaiczne, staroświeckie, skostniałe, hamujące rozwój nowoczesnej świadomości społecznej, jak i warstwy tradycji rewolucyjnej, demokratycznej. Te ostatnie wprowadzają w codzienny obieg myślowy operowanie pojęciami procesów społecznych, inicjatywy mas, zbiorowych instytucji i działań grupowych [--]. Wydaje się jednak, że w historycznej świadomości polskiego społeczeństwa rolę stosunkowo dużą odgrywa wciąż jeszcze tradycja pierwszego typu, czyli tradycja szlachecka, a także personalistyczna, heroistyczna. Reprezentuje ją ekipa bohaterów epoki i klasy dawno minionej, klasy, która dawno znikła wraz ze swoim kodeksem cnót z materialnego życia społecznego [--] jednakże nasza współczesność wymaga coraz większej wrażliwości intelektualnej i uczuciowej na zjawiska historii

${ }^{81}$ Ibidem. 
zbiorowej. Wymaga od ludzi na co dzień owej historiozofii przemian, która m.in. decyduje o ich dojrzałości do świadomego udziału w kształtowaniu historii ${ }^{82}$.

Ambitne zadanie postawiła autorka przed historiografią. Szło tu przecież o rewolucyjne imponderabilia, o oczyszczanie mentalności chłopów i robotników z klasowej świadomości szlacheckich wyzyskiwaczy, którzy niejako zza dziejowego grobu wciąż potrafili skutecznie powstrzymywać decydujący skok z królestwa konieczności do królestwa wolności. Szczęśliwie dla Jasienicy swoje historiozoficzne wyznanie wiary złożyła Bobińska w momencie, gdy podobne deklaracje nie mogły już liczyć na aktywne wsparcie polityczne. Taki polityczny „sukurs” doprowadziłby zapewne do uznania autora za wroga klasowego włącznie z wszelkimi towarzyszącymi temu konsekwencjami. W komentarzu Bobińskiej widać przywiązanie nie tylko do marksistowskiej teorii społeczeństwa, ale również do historiozoficznego, utopijnego schematu.

W metodologicznym kontekście, który towarzyszył twórczości historycznej Jasienicy, wyjątkowe były myśli wyartykułowane przez Gieysztora we wspomnieniu napisanym po śmierci autora Polski Piastów i Polski Jagiellonów. Gieysztor pisał:

Większość historyków zawodowych myśli dziś także o historii innej, historii o długim przebiegu, szerokim rytmie i oddechu, o procesach, choć schematyzm ich pojmowania wyrządził w minionych latach tyleż szkody w popularności nauki historycznej, co samym jej pracownikom. Myśli także o strukturach społecznych i psychicznych, o mentalności zbiorowej i indywidualnej, o dorobku własnym i o udziale tego dorobku w kulturze świata.

Czyżby Jasienica pozostał na te wezwania nieczuły? Na pewno nie. Wystarczy porównać horyzont Polski Piastów z nabrzmiałym myślami różnorakimi tomem Srebrnego Wieku, aby uprzytomnić sobie odbytą w ciągu lat bez mała dziesięciu drogę Jasienicy - syntetyka i pisarza historyczno-politycznego. ,Rozchodzenie się dróg władzy i Obojga Narodów Rzeczypospolitej" to już przykład analizy wielowarstwowej, w której pisarz i historyk dokonał sztuki niezwykle trudnej pisania dla ogółu Polaków i dla jego cząstki - fachowo przygotowanej i z obowiązku swego zawodu czujnej na historię ojczystą ${ }^{83}$.

Faktycznie. Można wręcz rzec, że pierwsza faza twórczości Jasienicy, choć metodologicznie całkowicie obca marksistowskim inspiracjom („,personalizm"), była ideologicznie spójna ze swoistą polityką historyczną reżi-

${ }^{82}$ C. Bobińska, op. cit.

${ }^{83}$ A. Gieysztor, Paweł Jasienica. Historyk polski, ,Tygodnik Powszechny” 1971, 34. 
mu (apologia Piastów, krytyka unii z Litwą itd.). Druga faza zaś choć z metodologicznego punktu widzenia wykorzystywała w pewnym przynajmniej zakresie wyniki badań historycznych inspirowanych marksizmem, ideologicznie oddalała się od oczekiwań partii.

\section{Wokół deterministycznej ułomności}

Metodologiczny charakter - aczkolwiek niezwiązany z zarzutami o „personalizm”, dla których swoistą trampoliną były modernizujące tendencje w historiografii światowej połowy dwudziestego stulecia eksponujące znaczenie obiektywnych procesów masowych - posiadały te uwagi na temat pisarstwa historycznego Jasienicy, w których podkreślano, iż sposób, w jaki prezentował on upadek Rzeczypospolitej, wspierał wyobrażenie ściśle zdeterminowanego biegu dziejów. Jest to o tyle interesujące, że, jak wiemy, Jasienica deklarował swój zdecydowany sprzeciw wobec wszelkiego rodzaju historiozoficznego fatalizmu. Argumentacja, do której się tu odwoływano, nie była niczym nowym, z czego zresztą jej autorzy doskonale zdawali sobie sprawę. Nawiązywała ona do dziewiętnastowiecznych sporów, jakie toczyli historycy - głównie, jak się zdaje, z krakowskiej i warszawskiej szkoły historycznej. Przedstawiciel tej ostatniej, Władysław Smoleński, był bodaj pierwszym uczonym, który wskazywał, że skupienie się na wyjaśnianiu przyczyn upadku Rzeczypospolitej, cechujące reprezentantów krakowskiej szkoły historycznej, prowadziło do wypromowania takiego obrazu dziejów Polski, w którym jej upadek był rezultatem bezalternatywnego i nieodwracalnego rozwoju. Źródeł tegoż upadku szukano już w czasach świetności Polski, obciążając przodków zupełnie niewspółmierną do faktycznej odpowiedzialnością za katastrofę znacznie późniejszą. Historiograficzna spuścizna, którą Jasienica konsumował z myślą o swoich książkach, była imponująco rozległa, a dług u niej zaciągnięty - zwłaszcza w kontekście recepcji dziewiętnastowiecznej tradycji historiograficznej - wyjątkowy. Przejmując poglądy poprzedników, nie uniknął również ich słabych stron. Wyartykułowane szczególnie wyraźnie w Polskiej anarchii przez Jasienicę myśli upatrujące w Artykułach henrykowskich i Pacta conventa pierwsze dziejowe kroki ku anarchii stanowiły wszak jądro słynnego tekstu Józefa Szujskiego o fatszywej historii jako mistrzyni fałszywej polityki (1877). „Dejaniry koszula paląca", która, zdaniem Szujskiego, przyczyniła się do zagłady Rzeczypospolitej, a która wiązała się z utrwaleniem zgubnej w skutkach formy ustroju politycznego, stała się polskim odzieniem już w szesnastym stuleciu. Kolejne etapy upadku, które wyodrębniał Jasienica, jak wskazywany wcześniej „pamiętny sejm” (1606) czy kontrreformacja, nie zdejmowały winy z chronologicznie wcześniejszych, kryjących w sobie zarodki upadku 
niefortunnych rozstrzygnięć, same zresztą przynależały do epoki znacznie poprzedzającej okres rozbiorów. I choć autor Polski Jagiellonów niejednokrotnie jeszcze opisując późniejsze dzieje Rzeczypospolitej podkreślał, że co rusz pojawiały się sposobności ratunku państwa, to jednak to deterministyczne nachylenie wyraźnie przebija z jego prac. Zwłaszcza że w osiemnasty wiek wkroczyła Polska, jego zdaniem, już w stanie anarchii tak zaawansowanej, iż jej upadek był przesądzony, a zależny wyłącznie od decyzji Moskwy.

Przeciwko ujęciu narzucającemu taki deterministyczny ogląd dziejów szlacheckiej Rzeczypospolitej zaprotestował Andrzej Zahorski, stwierdzając: „Nie podzielam tej opinii, nie sądzę, aby można szukać przyczyn upadku kraju w okresie jego świetności. A wszak i później w wieku XVII były momenty upadków i odrodzenia, a linia upadku nie biegła wcale tak karkołomnie w dół. To skomplikowane zjawisko ustrojowej sklerozy czy tylko schorzenia zostało nadmiernie, nieco schematycznie uproszczone"84. Tego samego wątku dotyczyły uwagi Tazbira zamieszczone w tekście poświęconym pisarstwu historycznemu Jasienicy. Tazbir zaznaczał, że odmalowany przez autora Polski Jagiellonów portret ojczystych dziejów niewątpliwie nie był wyłącznie zapisem choroby, na którą Polska zapadła jeszcze w XVI w., a która doprowadziła do jej upadku w wieku XVIII. Niemniej jednak książki Jasienicy wyraźnie wywoływały wrażenie, jakby kilkaset lat dziejów Polski zmierzało wprost do jej upadku. W ten deterministyczny schematyzm wbudowana była, wskazywał zasadnie Tazbir, równie schematyczna teza przeciwstawiająca permanentnie złych władców i zły rząd dobremu społeczeństwu. I jakkolwiek mogła się ona podobać szerokiej publiczności, aż nadto skłonnej do wyszukiwania $\mathrm{w}$ dziełach Jasienicy aluzji politycznych, a w tym przypadku pogląd o złej władzy i dobrym społeczeństwie aż się prosił o przeniesienie w czasy współczesne, to ze ściśle historycznego punktu widzenia budziła ona wątpliwości. Tazbir pisał: „I jeśli ostatnią dynastią, która wychodzi stosunkowo jeszcze obronną ręką spod pióra eseisty, są Piastowie, to chyba dlatego, iż wygaśnięcie tej dynastii nastąpiło na czterysta lat przed pierwszym rozbiorem. A więc mielibyśmy tu do czynienia z pewnego rodzaju przedawnieniem" ${ }^{85}$. Wiemy, że immunitet, którym Jasienica obejmował Piastów, wyłączając ich ze schematu dobry lud versus zła władza, wyrastał nie tylko z chronologicznej przepaści między okresem rozbiorów a panowaniem ostatnich piastowskich monarchów, lecz ze związania historii całej dynastii z mitycznymi pradziejami. Antyklerykal-

${ }^{84}$ A. Zahorski, 200 lat później, „Literatura” 1972, 6 (rec. P. Jasienica, Rzeczpospolita Obojga Narodów. Dzieje agonii).

${ }^{85}$ J. Tazbir, Pisarstwo historyczne Pawła Jasienicy, w: idem, Od Haura do Izaury, Warszawa 1989, s. 192. 
nie nastawiony Jasienica zbyt jednostronnie, zdaniem Tazbira, oceniał kontrreformację. Powiązanie jej z upadkiem państwa tylko wzmacniało deterministyczną wymowę jego dzieł, kładąc zarazem na barki siedemnastowiecznego ruchu zbyt duży ciężar odpowiedzialności za przyszłe klęski. Oceniając siedemnastowieczne zjawisko w świetle klęski rozbiorów, umieszczał je Jasienica w perspektywie zdecydowanie ahistorycznej. W jeszcze większym stopniu zniekształcał ogląd kontrreformacji zwyczaj odnoszenia doń - powiedzielibyśmy dzisiaj - metafory totalitaryzmu, wiążący się z narzuceniem przeszłości wybitnie już prezentystycznego punktu odniesienia. „To, co podoba się czytelnikom - pisał Tazbir - z satysfakcją odbierającym pogląd, iż «wprzężenie kraju w służbę nieosiągalnych a totalnych utopii» przynosi zawsze jak najbardziej katastrofalne skutki, nie może zyskać akceptacji historyków. Nasuwa się bowiem pytanie, czy uzasadnione jest mówienie o totalitaryzmie i totalitarnej ideologii w odniesieniu do epok wcześniejszych"86.

Na niemożność uwolnienia się z uścisku zakorzenionej przecież w polskiej tradycji historiograficznej tendencji do prezentowania dziejów szlacheckiego państwa w kategoriach wytyczonej i zaplanowanej z góry marszruty, dla której 1795 r. stanowił rodzaj chronologicznego finiszu, wskazywał w recenzji z ostatniego tomu Rzeczypospolitej Obojga Narodów Jerzy Jedlicki. Przesunięciu ulegał tu tylko punkt, w którym Polska wkroczyła na drogę bez odwrotu, drogę wiodącą już wprost do upadku państwa. Progiem wyznaczającym tym razem zdecydowanie deterministyczne cięcie była wojna północna. W jej wyniku dzieje polityczne Polski w wymiarze międzynarodowym toczyły się już wyłącznie w „królestwie konieczności”. Unicestwienie Rzeczypospolitej było już tylko kwestią czasu. Orędownik radykalnie woluntarystycznej wizji dziejów tym razem, jak podkreślał Jedlicki, ograniczał pole możliwego wyboru kierunku, w którym miały się potoczyć losy Polski, wyłącznie do wewnętrznego rozwoju szlacheckiego społeczeństwa. Ten zaś związany był, jak wspominaliśmy, z żywą i entuzjastyczną recepcją idei oświecenia, owocującą gorączką reformatorską i obywatelskim odrodzeniem. Przewrót umysłowy oznaczający ponowne włączenie się w główny nurt dziejów europejskiej kultury zyskiwał entuzjastyczne oceny Jasienicy pomimo tego, że wiązał się z próbą naprawy Rzeczypospolitej, której gwałtowność i radykalizm w istocie przyspieszyły tylko zgon państwa. Nie obciążało to jednak konta reformatorów, gdyż upadek Polski był już od wielu lat rozstrzygnięty. Stanowisko takie oznaczało, iż oceniając wysiłek reformatorski Polaków, nie zadawał sobie Jasienica pytania o to, czy wysiłek ten sprzyjał utrzymaniu niepodległości.

${ }^{86}$ Ibidem, s. 187. 
Jedlicki wskazywał, że charakterystyka ostatnich lat szlacheckiego państwa bazująca na przekonaniu, iż w kontekście polityki zewnętrznej jego dzieje toczyły się w obrębie królestwa konieczności, „uchyla siłą rzeczy jako nieistotne pytanie o pragmatyczną skuteczność i polityczną racjonalność działań oświeceniowych reformatorów państwa, ponieważ wystarczy, że działania te realizowały takie autonomiczne wartości, jak wyzbycie się klasowego egoizmu, myślenie kategoriami europejskimi i odwaga ruchu ku swobodzie" ${ }^{87}$. Uwaga ta nabiera szczególnej mocy w zestawieniu ze zgłaszanymi przecież wyraźnie przez Jasienicę pretensjami do przekształcenia refleksji nad dziejami w swoiste laboratorium rozumu politycznego. Z chwilą wkroczenia w obszar królestwa konieczności dzieje Polski utraciły dotychczasowe walory pola dogodnego do przeprowadzania eksperymentów myślowych, służących zgłębianiu tajników rozumu politycznego. Tymczasem o sensowną ocenę ostatnich lat Rzeczypospolitej można było się pokusić, zachowując kryteria politycznej racjonalności. Jak zauważał Jedlicki, ,jeżeli się stanie na stanowisku, że w biegu spraw ludzkich nic nie jest z góry przesądzone w sposób ostateczny, że zatem walka o ocalenie Rzeczypospolitej toczyła się do końca choćby z jedną szansą na sto - to wtedy dla oceny Konstytucji nie ma znaczenia to, czy była pierwsza czy dziesiąta, ani co o niej powiedział Edmund Burke" 88 . Odrzucając deterministyczne przesłanki Jasienicy, Jedlicki postanowił przyłożyć do postępowania reformatorów miare politycznego rozumu, co pozwoliło obnażyć popełnione przez nich błędy. W imię nieuzasadnionego zupełnie, jak twierdził, forsowania idei przekształcenia monarchii elekcyjnej w dziedziczną, budząc przy tym „natychmiastową czujność wszystkich potężnych sąsiadów”, twórcy Konstytucji 3 Maja „poszli na hazard: na zamach stanu, na złamanie pactów conventów, na ostentacyjne prowokowanie Najjaśniejszej Gwarantki. Hazard był gruby, bo nie stała za nim siła zdolna do odparcia interwencji, z którą liczyć się należało od początku. Hazard był niekonieczny, ponieważ w tym układzie sił, jaki się ukształtował na sejmie w roku 1791, istniała już realna szansa na to, że rzeczywiście nieodzowne dla ratowania państwa reformy dałyby się przeprowadzić w drodze żmudnego wprawdzie i rozwlekłego, ale w końcu skutecznego «ucierania» w izbie, o czym świadczy sukces znakomicie rozegranej batalii o Prawo o Miastach". W związku z tak ślepym przywiązaniem szlachty do elekcji należało jedynie zatroszczyć się o jej udoskonalenie, znosząc elekcję viritim i wprowadzając w jej miejsce na przykład wybór króla

${ }^{87}$ J. Jedlicki, Requiem dla Rzeczypospolitej, „Więź” 1972, 9, s. 15.

${ }^{88}$ Ibidem, s. 17. 
przez sejm. Celem zasadniczym reformatorów było wszak wzmocnienie władzy centralnej. Mogło to być osiągnięte bez wprowadzania dziedziczności tronu. Jak pisał Jedlicki, „doprawdy nie było i nie ma dostatecznych podstaw do przekonania, że warunkiem efektywnej władzy jest jej dziedziczne przekazywanie" ${ }^{89}$.

\section{W zderzeniu z emigracyjną myślą historyczną}

Interesująco przedstawia się emigracyjna recepcja pisarstwa historycznego Jasienicy. Oto dwie skrajnie odmienne opinie sformułowane przez autorów pozostających po wojnie na emigracji. Krytycznie o Jasienicy wypowiedział się publicysta Józef Mackiewicz. Pisał on:

Jasienica napisał kilka książek o tematyce historycznej, w tej liczbie o Jagiellonach, zgodnie z doktryną historyczną wytyczoną w PRL. Że np. błąd Jagiellonów polegał na tym, iż parli na wschód, przeciw Moskwie, zamiast zwrócić się na zachód, przeciw Niemcom. Że np. ,czerwoni” w powstaniu r. 1863 mieli rację, a nie „biali” itp.Jego poglądy osobiste mogły się pokrywać z obowiązującą doktryną historyczną. Nie powinniśmy jednak oszukiwać siebie, że mógł napisać odwrotnie ${ }^{90}$.

W odmiennym tonie o Jasienicy pisał historyk Marian Kukiel. Oto jego opinia:

Jasienica zaś bawiąc się obroną „makiet”, bo „nie wyobraża sobie większego nieszczęścia dla kultury niż zaniechanie sporów na temat dziejów narodu", dobiera się do miotły i wymiata nagromadzone śmiecie; pastwi się nad „feudalizmem”, który rzekomo panował u nas od wspólnoty pierwotnej po rok 1864 i stał się workiem, w którym mieści się tysiąc lat naszej historii. Pastwi się nad pomawianiem Polaków, że po unii z Litwą zaludnili miasta, opanowali wsie, wynarodowili rządzące klasy społeczne Litwy i Rusi, przywłaszczyli wszystko, co przedstawiało wartość materialną, w pierwszym rzędzie władzę i ziemię ${ }^{91}$.

Powyższe oceny zdają się niemal biegunowo odmienne. Mackiewicz na pierwszy plan wysunął zbieżność poglądów Jasienicy z, jak to ujął, „,doktryną historyczną" obowiązującą w kraju. Kukiel natomiast wyeksponował dystans dzielący poglądy Jasienicy od poglądów wyłożonych w stalinowskiej makiecie dziejów Polski. Ocena Kukiela brała zatem pod uwagę peerelowski kontekst. Umieszczenie myśli historycznej Jasienicy na tle

\footnotetext{
${ }^{89}$ Ibidem, s. 18.

${ }^{90}$ J. Mackiewicz, Casus Paweł Jasienica, „Wiadomości” 1971, 3 (1294), s. 2.

${ }^{91}$ M. Kukiel, T. Pełczyński, Leon Beynar - Paweł Jasienica 1909-1970, „,Teki Historyczne"1969-1971, t.16, s. 360.
} 
poglądów tworzących emigracyjny kanon interpretowania dziejów Polski, zarysowanie swego rodzaju katalogu rozbieżności z jednej i wyodrębnienie punktów stycznych z drugiej strony, pozwoli lepiej zrozumieć różniące się wszak w sposób istotny od siebie opinie Kukiela i Mackiewicza.

Zajmowane przez Jasienicę w pierwszej fazie twórczości stanowisko, łączące utratę ścisłego związku z europejskimi normami rozwoju historycznego ze wstąpieniem na drogę trwałego przymierza z Litwą, stawiało myśl historyczną autora Polski Jagiellonów w ostrej opozycji do poglądów powszechnie głoszonych na emigracji. Biegunowo od nich odległe było bowiem ujęcie obciążające unię odpowiedzialnością za degenerację myśli i praktyki politycznej, której zgubne skutki dodatkowo potęgował fakt niepotrzebnego uwikłania się w wojny z Rosją. W interpretacjach emigracyjnych wojny ze wschodnim sąsiadem były do pewnego stopnia nieuniknione. Państwo carów było bowiem ucieleśnieniem wschodnich despotii programowo nastawionym na podbój. Unia spełniła swoją rolę w tym sensie, że umożliwiła wielowiekowy skuteczny opór wobec imperialnej polityki Rosji. Lansowanej w kraju ekonomistycznej interpretacji unii realnej z Litwą przeciwstawiano na emigracji ujęcie "geopolityczne", upatrujące w zagrożeniu moskiewskim jeden z zasadniczych czynników, który zadecydował o zaciśnięciu więzów z litewskim partnerem w 1569 r. W duchu strategicznej konieczności interpretowano włączenie w tymże roku do Korony trzech wschodnich województw ${ }^{92}$.

Sprzeczne z emigracyjnym kanonem myśli historycznej były poglądy Jasienicy dotyczące oceny i interpretacji chrztu Polski. Jasienica był przywiązany do liberalno-oświeceniowej tradycji, czemu towarzyszył bezkompromisowy antyklerykalizm przenikający wszystkie jego prace. Między tą postawą a poglądem łączącym krystalizację wysokich standardów kultury Zachodniej w kraju Piastów z erą przedchrześcijańską zachodził swoisty związek zgody. W tym właśnie punkcie kolizja ze stanowiskiem prezentowanym na emigracji (np. przez Oskara Haleckiego) była bardzo poważna. W interpretacji Jasienicy ranga chrztu była bowiem bez porównania mniejsza od tej, na którą zasługiwał on zdaniem zdecydowanej większości autorów emigracyjnych. Zwalczając „wplątanie" chrztu w teorię formacji, dawali oni wyraz poglądom, które nie tylko eksponowały jego znaczenie i wyjątkową rolę w gruntownym przekształcaniu relacji międzyludzkich, ale wręcz wiązały go $z$ właściwym początkiem dziejów Polski, czyniąc zeń wydarzenie na trwałe określają-

${ }^{92}$ Zob. A. Mękarski, Między historiozofia a polityką. Historiografia Polski Ludowej w opiniach i komentarzach historyków i publicystów emigracyjnych 1945-1989, Warszawa 2011, s. 91-109. 
ce charakter Polski i jej losów. Matryca polskich wartości fundamentalnych, ulokowana przez Jasienicę w erze przedchrześcijańskiej, w optyce emigracyjnej łączyła się właśnie nierozerwalnie z rokiem 966 i religią katolicką.

Negatywny stosunek do unii z Litwą z pierwszej fazy twórczości Jasienicy, ,laicki racjonalizm”, jakże sprzeczny z emigracyjną , duchologią", krytyczna ocena roli białych w powstaniu styczniowym mogły razić emigracyjnego autora, prowokując dającą się zrozumieć krytykę.

O wiele ciekawsze jednak, a zarazem ważniejsze z punktu widzenia prezentacji dorobku historycznego Jasienicy są zawarte w tomach poświęconych Rzeczypospolitej Obojga Narodów poglądy, które oprócz tego, że pokrywały się z opiniami emigracyjnymi, to na dodatek mieściły się w korpusie argumentów wykorzystywanych na emigracji do walki $\mathrm{z}$ interpretacjami z lat pięćdziesiątych. W stalinowskim ujęciu dziejów Polski krytyczna ocena unii z Litwą wiązała się ściśle z kreowaniem bardzo niekorzystnego wizerunku polsko-litewskiej Rzeczypospolitej jako państwa, w którym rozległa gospodarcza eksploatacja włościan ograniczała możliwość dynamicznego rozwoju kraju, potęgując jego polityczną niemoc. Zagarnięcie w wyniku unii ziem wschodnich, które - jak wówczas pisano - ciążyły naturalnie do Rosji, przyczyniło się w sposób decydujący do petryfikacji feudalizmu w Polsce. By zneutralizować krajową krytykę społecznego oblicza szlacheckiej Rzeczypospolitej, uciekano się w środowisku emigracyjnym do kreślenia porównań między sytuacją włościan w Rzeczypospolitej z jednej a sytuacją włościan w Rosji z drugiej strony. Z tej komparatystycznej potyczki Polska wychodziła zdecydowanie obronną ręką ${ }^{93}$ W opinii autorów emigracyjnych takie paralelne ujęcie miało po pierwsze umożliwiać osadzenie sądów historycznych we właściwej - historycznej właśnie - perspektywie, a zarazem obnażać instrumentalne stosowanie marksistowskiego wokabularza w krajowej historiografii. Celem tych porównań było bowiem wykazanie sprzeczności między deklaracjami opowiadania i oceniania dziejów ze względu na zachodzące w nich procesy emancypacji społecznej a uznaniem, że ziemie wschodnie z naturalnych względów powinny znaleźć się w obrębie państwa rosyjskiego. Gromy, jakie ciskano na I Rzeczpospolitą za ekonomiczną eksploatację warstwy chłopskiej, szły w parze z wpychaniem ludności ukraińskiej i białoruskiej w objęcia Rosji, chociaż ze społecznego punktu widzenia sytuacja przedstawiała się tam jeszcze gorzej niż w Polsce. Wydobywając na wierzch tę sprzeczność, zarazem odbierano marksizmowi

${ }_{93}$ Patrz na przykład: W. Wielhorski, Wielkie Księstwo Litewskie w komunistycznej historii Polski, „Teki Historyczne” 1956-1957, t. 8, s. 47. 
wymiar stricte metodologiczny, sprowadzając go do poziomu broni ideologicznej legitymizującej carsko-sowieckie podboje.

Wątek, w którym ocena społecznego oblicza szlacheckiej Polski krzyżowała się z praktyką angażowania marksizmu do działań na rzecz legitymizowania nowego porządku społeczno-politycznego i sankcjonowania sowieckich podbojów, znalazł swoje doskonałe odzwierciedlenie w „sporze o cezurę 1795 roku". W wydanych w 1961 r. Dziejach Polski porozbiorowych, emigracyjnej kontrpropozycji dla Makiety, Kukiel zaatakował podjętą w kraju próbę usunięcia 1795 r. z rzędu przełomowych momentów w dziejach Polski. Redaktorzy Makiety oznajmiali we wstępie, iż w świetle teorii formacji data ostatniego rozbioru w istocie nie zasługiwała na wyróżnienie, gdyż i „przed rozbiorem, i po nim klasa panująca stosuje w zasadzie te same metody i formy wyzysku i ucisku, a klasa wyzyskiwana odpowiada na nie tymi samymi w zasadzie metodami walki"94. Krytykując takie podejście, Kukiel wskazywał, iż upadek państwa oznaczał przerwanie zakrojonego na szeroką skalę i znajdującego się w fazie energicznej realizacji procesu reform, które nie tylko eliminowały wady ustroju politycznego szlacheckiej Rzeczypospolitej, ale miały też doniosłe znaczenie w kreowaniu pożądanego - i to właśnie ze społecznego punktu widzenia - biegu wydarzeń. Nieprzypadkowo w rozdziale drugim swojej syntezy Kukiel podkreślał społeczny regres wynikający z zagłady szlacheckiej Rzeczypospolitej. Najsroższe cięgi zebrała Rosja, która „nie postęp wniosła, ale unicestwienie wszelkiego dzieła postępu" ${ }^{95}$. Również w zaborze pruskim i austriackim chłop „uzyskiwał mniej niż dawał mu Kościuszko" ${ }^{\text {". W }}$ opinii Kukiela w ramach autentycznej realizacji programu opowiadania historii z punktu widzenia klas upośledzonych wyjątkowy status 1795 r. nie mógł budzić żadnych wątpliwości. O stosunku do daty ostatniego rozbioru decydowała nie szermująca pojęciem emancypacji metodologia, ale naciski natury politycznej. W 1795 r. z mapy Europy znikało państwo, którego granice, w porównaniu z tymi, które ustalono w 1945 r. w Jałcie, sięgały daleko poza linię Curzona. Wyróżnianie upadku tego państwa zdawało się kolidować z ideologicznym dążeniem do wykreowania obrazu dziejów uzasadniającego zmiany terytorialne, jakie zaszły po 1945 r. Co ciekawe, eksponując społeczny wymiar dokonań Sejmu Wielkiego, Kukiel wspierał się tezami historyka z kraju. W 1959 r. Jan Dihm opublikował monografię Sprawa konstytucji ekonomicznej z 1791 roku (Wrocław 1959), której główna teza głosiła, iż artykuł czwarty Kon-

\footnotetext{
${ }^{94}$ Historia Polski. Makieta, s. 5-6.

${ }_{95}$ M. Kukiel, Dzieje Polski porozbiorowe 1795-1921, Londyn 1993, s. 43.

${ }^{96}$ Ibidem, s. 56.
} 
stytucji 3 Maja był jedynie wstępem do dalszych ustaw mających gruntownie polepszyć sytuację ludności włościańskiej. Przygotowanie projektu konstytucji ekonomicznej, której tekst niestety się nie zachował, powierzono księdzu Michałowi Ossowskiemu. Postępowe rozwiązania z uwagi na rozbiory nie zostały wprowadzone w życie.

Tę społeczną atrakcyjność Rzeczypospolitej kontrastującą z niedolą chłopską w państwach ościennych eksponował również Jasienica. „Nawet zanarchizowana - pisał - Rzeczpospolita była magnesem dla uciśnionych [tj. włościan z Rosji i Prus przybywających w granice Polski - A. M.], cóż by się dziać zaczęło, gdyby zaprowadziła u siebie ład, wzmocniła władzę centralną, z natury powołaną do troski o wszystkich poddanych" ${ }^{97}$. To kontrfaktyczne ujęcie (cóż by się działo, gdyby) doskonale współgrało ze sposobem argumentacji Kukiela, do którego odwoływał się on w swoim opus magnum. Omawiając reformę rolną w Rzeczypospolitej Krakowskiej, przeprowadzoną pod przewodnictwem Marcina Badeniego, a zamieniającą pańszczyznę na czynsze, emigracyjny historyk pisał: „Ten przebieg sprawy chłopskiej daje pojęcie o tym, jaki byłby jej przypuszczalny przebieg w całej Polsce, gdyby utrzymała się Rzeczpospolita z Konstytucją 3 Maja" ${ }^{98}$. Co więcej, Jasienica, eksponując te postępowe pierwiastki tkwiące w narodzie, podkreślając zakres procesów naprawy, w czym dołączał do grona zwolenników teorii odrodzenia w upadku, podobnie jak Kukiel wskazywał na wysiłki czynione przez ks. Ossowskiego. Tak jak Kukiel, bez zastrzeżeń zdawał się akceptować tezy wyłożone w pracy Dihma z 1959 r. Jest to symptomatyczne w świetle całkiem zasadniczej krytyki, z jaką monografia ta została przyjęta w kraju.

W poświęconej jej recenzji Emanuel Rostworowski wskazywał, iż projekt postępowej ustawy w ogóle nie istniał, a planowane dziełko o konstytucji ekonomicznej było imprezą o charakterze publicystycznym, które należało potraktować co najwyżej jako wytyczną programową i źródło inspiracji dla przyszłych poczynań ustawodawczych ${ }^{99}$.

Poglądy, które głosił Jasienica w drugiej fazie swojej twórczości, doskonale komponowały się z tymi fragmentami syntezy Kukiela, które stanowiły kontrpropozycję dla interpretacji stalinowskich. W tym kontekście przytoczona wcześniej ciepła opinia Kukiela o Jasienicy staje się zupełnie jasna i zrozumiała.

Wreszcie nie mniej istotne zbliżenie stanowisk między Kukielem a Jasienicą zaszło w obrębie założeń teoretyczno-metodologicznych.Jasienica

${ }^{97}$ P. Jasienica, Rzeczpospolita Obojga Narodów. Dzieje agonii, s. 320-323.

${ }^{98}$ M. Kukiel, op. cit., s. 195.

99 E. Rostworowski, W sprawie konstytucji ekonomicznej z 1791 r. Na marginesie książki Jana Dihma, PH 1960, 4, s. 732, 747. 
przywracał sferze politycznej należne jej znaczenie. To od decyzji poszczególnych władców - a nie od obiektywnych interesów gospodarczych klas uprzywilejowanych - zależeć miały losy całych narodów.

Koncepcja dziejów Polski Jasienicy opierała się na micie założycielskim. Monarchia Piastów urzeczywistniała pierwiastkowe zasady ustanowione przez jej legendarnych ojców-założycieli, wyznaczające parametry dziejowego sukcesu. W duchu wzorcowych reguł politycznego umiaru i tolerancji wychowywany był przez stulecia naród, który potrafił skutecznie przyswoić te reguły. Klęski, których doświadczał, wynikały z wpływów obcych - raz byli to litewscy magnaci, raz zaproszeni do kraju władcy. Taka obrona narodu przed zarzutami o prowokowanie dziejowych katastrof kryła w sobie, jak się zdaje, jego sakralizację. W ramach tego mitycznego ujęcia ewoluowała ocena unii z Litwą i, co się z tym wiąże, ocena Polski jagiellońskiej. W pierwszej fazie twórczości prezentował Jasienica bardzo krytyczny stosunek do państwa rządzonego przez drugą w jego dziejach dynastię. W pracach zaś poświęconych Rzeczypospolitej Obojga Narodów to samo państwo stawało się cywilizacyjnym wzorem do naśladowania. W sferze metodologicznej był Jasienica obrońcą tradycyjnej historii politycznej, a zarazem krytykiem prezentowania dziejów Polski w kategoriach zaczerpniętych z teorii formacji społeczno-ekonomicznych. Uwagi recenzentów z kolei rozbijały mityczną strukturę przedstawionego przez Pawła Jasienicę ujęcia dziejów Polski.

\section{Between Myth and Political Rationality. Paweł Jasienica's Interpretation of Polish History and its Reception in the Era of the Polish People's Republic}

Known for writing popular books on the history of Poland, Paweł Jasienica (1909-1970) established himself as one of the most distinguished, non-fiction authors of his era. Looked upon as an history writer who exercised his craft in defiance of the Marxist paradigm, he gained much popularity in the Polish People's Republic, reaching bestseller status. It would probably be difficult to find a history-lover - at least during the Communist era - who never read one of his books.

The paper presented here deals with Jasienica's historical thought. It has been divided into two parts. The first one aims at offering some insight into key elements of his vision of Polish history, while the second one deals with the reception of his books in the period of the Polish People's Republic. The author advances the thesis that the interpretation of Polish history put forward by Jasienica had the foundation myth at its core. It was already unknown predecessors of Mieszko the First whom Jasienica wanted to give credit for establishing a code of political action to be followed by future generations of the Polish people. Follow- 
ing the code was necessary to keep the country on the right track. It included abandonment of imperialistic tendencies in what - for want of a better word can be referred to as foreign policy. Founding fathers of Poland were perspicacious enough to know that they should confine themselves to uniting the so-called "core" Polish lands. Not only were they prepared to drop any plans for territorial expansion but they also fostered the policy of religious toleration, which went hand in hand with their willingness to forge alliances with Pagan rulers whenever it was found necessary for the protection of the country.

Jasienica was unstinting in his praise of almost all historical rulers of the Piast dynasty for their adherence to the code just mentioned. Their attitude allowed Poland to survive all historical storms. Unlike the Piast monarchs, however, those of the Jagiellonian dynasty failed - argued Jasienica in the first phase of his writing career - to rely for the conduct of their policy on the ancient principles, inculcating into the Polish politics standards and habits which compared highly unfavorably with those once established by legendary rulers of Poland. With the conclusion of the Polish-Lithuanian Union, the country embarked on a policy clearly out of tune with what Jasienica considered to have been the real Polish ways, veering sharply off its right European track.

However, in his last books he changed his views to a surprising extent. The union which at first seemed to be a source of most problems Poland was supposed to struggle with for years to come, now, in the trilogy written in the second phase of his career and dealing with the history of Poland from 1572 to 1795 was glorified as a great historic achievement worth copying by other European nations.

The most important conclusion arrived at in the second part of the paper is that critical remarks to be found in the reviews of his books tended to fracture the aforementioned mythical framework of Jasienica's interpretation of Polish history.

Artur Mękarski 